\title{
Path Modeling The Antecedent Factors To Consumer Repurchase Intentions For Advanced Technological Food Products: Some Correlations Between Selected Factor Variables
}

George S. Spais, (E-mail: gspais@cc.uoi.gr), University of Ioannina, Greece Kostantinos Vasileiou, (E-mail: kovasil@cc.uoi.gr), University of Ioannina, Greece

\begin{abstract}
The major objective of this study is to test a model that explains consumer repurchase intention for technological advanced food products in developing economies. We address the core research themes of our study using a survey of 800 Greek households. Our intention is to test consumers' perceptions in order to investigate the potent influence of some set of variables, (discussed in the consumer research literature), in order to analyze repurchase intention for technological advanced food products in developing economies. The proposed model is not intended to explain all consumption behavior related to alternative food products. We believe that the final findings of our research can advance retailers' strategic tries as it seems that geographical differentiation is needed to be considered, in terms of pricing and promotion planning at a store level in developing countries.
\end{abstract}

\section{INTRODUCTION}

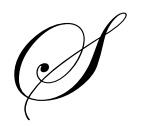

ome studies have concentrated on determining the basic antecedent variables to repurchase intention for food products such as Tomlison (1994) and van der Pol and Ryan (1996). Mai and Ness (1999) study has considered the critical encounters and relationships between these variables.

Furthermore, a consumer behavior model, which holistically defines the processes by which consumers make a choice between several competing brands or producers, is still to be developed. Some progress in this direction has been made by the evaluation of known alternatives being factored into consumer assessments (mostly in the service industry), via the disconfirmation of expectations (Bearden and Teel, 1983; Bolton and Drew, 1991; Boulding et al. 1993; Cadotte et al., 1987; Oliver 1980; Oliver and Bearden, 1985). While this approach measures the difference between pre and post consumption assessments, it provides only a partial explanation of how consumer retention mechanisms might operate.

The major objective of this study is to test a model that explains consumer repurchase intention for technological advanced food products in developing economies.

We address the core research themes of our study using a survey of 800 Greek households. Our intention is to test consumers' perceptions in order to investigate the potent influence of some set of variables, (discussed in the consumer research literature), in order to analyze repurchase intention for technological advanced food products in developing economies. The proposed model is not intended to explain all consumption behavior related to alternative food products. 
The basis of our research model is derived from the repurchase intention analysis by Hellier et al. (2003). The theoretical basis of the research model is derived from several sources. The model is developed from the satisfaction, attitude and intention relationships examined by Oliver $(1980,1981)$, from the analyses of consumers' understanding of genetic modification technology by Frewer et al., (1994), Miller and Huttner (1995) and Jones (1996) and from the analyses of consumers' understanding of products' environmental friendliness by Sriram and Forman (1993).

\section{RESEARCH ON REPURCHASE INTENTION FOR FOOD PRODUCTS}

\section{Brand Preference Upon Repurchase Intention}

The relationship between consumer's attitudes with respect to a generic product and the evaluations they carry out of a specific product is double. On the one hand, the models that estimate an individual's attitude towards a product according to his/her perceptions - weighted or not - regarding a set of relevant attributes are well known. The pioneering and most outstanding models from this approach are those of Rosenberg (1960) and Fishbein (1963). Despite the immense influence of these models, a period of discussion with respect to aspects such as the importance certain non-cognitive antecedents may have in the generation of attitudes was initiated. It has been previously mentioned the increasing role affective processes are being granted. In fact, regarding to this question, some empirical evidence of the independence of these factors with respect to the cognitive ones has already been obtained (for example, in a recent article by Kim et al., 1998). Nevertheless, the discussion process is still alive as it is shown by the interesting debate held by Fishbein and Middlestadt (1997) with some of their critics like Miniard and Barone (1997).

On the other hand, the causal relationship between attitudes and evaluation may have the inverse direction. Thus, it is predictable that previous attitudes towards a product category may also affect the specific perceptions an individual obtains from a particular offer or brand. In this respect, Gardner (1985) showed that a consumer's affective responses are capable of influencing cognitive processes such as product evaluation or its recollection. In some other more recent studies, results that support this hypothesis were obtained. In this way, Allen et al. (1992) observed the effect of emotions on the cognitive component of attitudes (measured as opinions) and the influence of both dimensions on behavior. Also Kelley and Hoffman (1997) confirmed that the positive affects felt by the consumer when a product or service is provided affect the evaluation this one makes of its quality. Likewise, the theories about the distortion of information explain the differences among individuals when it comes to perceiving and evaluating products (Meloy 2000). On the other hand, previous global evaluations the consumer has made of the product influence posterior evaluations and purchase decisions (Lynch et al., 1988).

\section{Consumer Satisfaction Upon Repurchase Intention}

A direct positive relationship between consumer satisfaction and repurchase intention is supported by a variety of product and service studies (Anderson and Sullivan, 1993; Bolton, 1998; Fornell, 1992; Oliver, 1980; Woodside et al., 1989). These studies establish that overall consumer satisfaction is strongly associated with the behavioral intention to return to the same product or service provider. However, it must be kept in mind that the direct positive relationship of satisfaction upon repurchase intention is a simplification of the matter. While consumer satisfaction is a major factor, it is only one of the many variables that can impact upon consumer repurchase intention (Jones and Sasser, 1995; Srinivasan, 1996; Storbacka et al., 1994).

\section{Perceived Value Upon Repurchase Intention}

Kuznesof and Ritson (1996) suggest that the acceptability of genetically modified (GM) products increases with, among other things, higher use, perceived benefits, and perceived increase in quality of the product (particularly taste and naturalness). Frewer's (1997) results showed that perceived benefits had the most important influence on consumer purchase decisions, such as environmental impact and health-related concerns. Steenkamp (1989) and Kyriakopoulos and Oude Ophuis (1997) maintained that the concepts of perceived value can be applied to organic food research and have provided useful insights into buying behavior. Kyriakopoulos and van Dijk (1997) also applied the concepts of perceived value when examining how consumers form their purchase intentions for organic 
extra virgin olive oil. They have presented a model for the evaluation of organic foodstuff at the "postconsumption" level.

\section{Perceived Quality Upon Repurchase Intention}

Steenkamp (1989) and Kyriakopoulos and Oude Ophuis (1997) maintained that the concepts of perceived quality can be applied to organic food research and have provided useful insights into buying behavior. Kyriakopoulos and van Dijk (1997) also applied the concepts of perceived quality when examining how consumers form their purchase intentions for organic extra virgin olive oil. They have presented a model for the evaluation of organic foodstuff at the "postconsumption" level.

\section{Perceived Technological Risk Upon Repurchase Intention}

Holm and MØhl study (2000) identified that the buying choice among relative meat products is determined by the way in which meat is produced and processed in modern agriculture and industry

\section{BACKGROUND STUDY}

It is generally recognized that, despite the green trend in consumer values and attitudes, there are still different barriers to the diffusion of the ecologically oriented food consumption style. The barriers of technological advanced food consumption stressed in the marketing literature include, for example, consumers' reluctance to pay higher costs, not only in money but also in time and effort, usually associated with organic products, and their unwillingness to accept sacrifices in the subjectively perceived quality of the organic variant.

In addition to this difficulty associated with conflict between personal and environmental benefits, technological advanced food consumption is restrained by the complexity of the information related to the characteristic associated to products and the impact of the mode of production on the environment.

\section{Food Choice Decisions And Food Consumption Behavior}

Food choice is often influenced more by the psychological interpretation of product properties than the physical properties of products themselves (Rozin et al., 1986). Perception of food safety risk is one such psychological interpretation, which influences the attitudes and behavior of consumers with respect to the purchase of food products. Thus, perception of food safety risk has consequences for both consumer and producer welfare, and the overall effectiveness and efficiency of the food supply chain. This is especially the case where there is considerable divergence between what might be called objective, technical assessments of risk and subjective, psychological assessments of risk. Such divergence may arise because of inadequacy of risk communication systems and/or a loss of confidence or trust in the food supply chain and its various agents, including regulators.

Through their food choice decisions and consumption behaviour, consumers may be exposed to a number of potential food hazards, associated with different degrees of harm. These can be related to diverse factors such as farming methods, food processing techniques, hygiene standards in the home and in the catering sector, lack of personal and/or expert knowledge (about, for example, the extent of the risk, or health protection mechanisms) and the availability of information. People's behaviors and associated attitudes towards a particular hazard are driven more by psychologically determined risk perceptions than the technical risk estimates (such as mortality rates). Research has consistently demonstrated that factors such as whether a given hazard is dreaded or worried about, perceived to be involuntary, unnatural or potentially catastrophic determine public perception of potential hazards (Sparks and Sheperd, 1994; Fife-Schaw and Rowe, 1996; Kuznesof and Ritson, 1996; Frewer at al., 1998; Marris et al., 1998). Risk perception can also be influenced by personal experience with a hazard (Barnett and Breakwell, 2001), and by affective factors, such as "worry" (Baron et al., 2000) and level of "anxiety" (Bouyer at al., 2001). It is these psychological factors, which determine people's risk-taking or self-protective behaviors. 
There is some evidence of a difference between expert and public perceptions of the risks of food hazards (see Rowe and Wright, 2001). For example, whilst food safety experts judge microbiological hazards to be the main risk to health from food, public perception of the risk of microbiological hazards is considerably lower than the perceived risk of other potential hazards like pesticides and food additives (Brewer at al., 1994). In the past, expert groups have complained that public priorities for risk mitigation activity are different from those promoted by expert communities. However, Frewer and Salter (2002) argue that the "firewalls" created between expert groups and the wider public is no longer appropriate in a climate of regulatory transparency and information availability. The rise of the "consumer citizen" and informed consumer choice, and the diminished role of the "expert" as a result of the wide availability of specialist information also contribute to this conclusion. Regulators need to take account of both consumer priorities for risk mitigation and technical risk estimates when managing the risks associated with food hazards. Thus, it is necessary to understand exactly what consumers are worried about.

Early research into public risk perception focused on the nuclear industry and issues of power plant safety and radioactive waste management, and as such, focused on technological risks and regulatory institutions with responsibility for risk management within this hazard domain. Typically, comparisons were made between technological risks and risks that occurred naturally, the policy community frequently arguing that public responses to technological risk were out of proportion to their true potential for harm [see for example, Adams (1998), for discussion]. The assumption has been, therefore, that the public conceptualizes technological and naturally occurring hazards in fundamentally different ways. Research into risk perception and technological hazards (such as nuclear power, food irradiation, genetic modification of food) has focused on technology acceptance, whereas research into lifestyle hazards (such as individual nutrient consumption, hygiene practices and cigarette use) has focused on behaviour change.

There is evidence that public perception of different food safety issues (such as food poisoning, fat consumption, chemical residues in food, and genetically modified food) is characterized by quite different risk "profiles" (e.g. Frewer et al., 1994; Sparks and Shepherd, 1994; Fife-Schaw and Rowe, 1996; Miles and Frewer, 2001; Kirk et al., 2002). Food hazards can be classified as falling into a number of categories, including "technological" or "lifestyle", in terms of how they are perceived by consumers. The existence of such a classification has not, to date, been subject to rigorous empirical testing. There is evidence in the food domain that there are differences in perception of technological and lifestyle hazards, such that people believe that they have more knowledge and more personal control over lifestyle hazards than technological hazards; furthermore, some lifestyle hazards are judged to pose less of a risk than technological hazards (Frewer et al., 1994).

\section{Technological Risk For Food Products}

According to Yeung and Morris there are three (3) types of food risks: (a) microbiological risk, (b) chemical risk and (c) technological risk. Technological risk refers to the possible negative consequences of technological advancements in food products, such as genetic modification (GM) of food. Technology has contributed multiple benefits in terms of food safety and increased food availability in general (Marshall, 1994; Buckland, 1997). There may also be public health risks associated with potential toxic or allergic effects of the GM organisms or environmental effects resulting from the accidental release of GM organisms (Ford and Murphy, 1998). Most people have a limited understanding of GM technology because it is novel and complex (Frewer et al., 1994; Miller and Huttner, 1995; Jones, 1996). There is diversity of opinion expressed by scientists and other experts of the possible implications for public health (NOI, 1999a, b) and this scientific debate can raise the sense of uncertainty about GM foods amongst a less informed public (Gregoriadis, 1999; Pollack, 1999; Weiss, 1999).

People tend to be suspicious of new technologies, often perceiving that the risks will outweigh the potential benefits, especially when the relative advantage of the technology is untested or unclear (Frewer and Shepherd, 1998). It is difficult to predict how consumers will accept new products and processes (Clarke and Moran, 1995). In situations where the public is relatively uninformed, public attitudes are often dependent on the type and level of media coverage (Miles and Frewer, 1999). Indeed, the popular press in particular has often plugged the information gap in some cases, some would argue, more with a view to selling copy than increasing the knowledge base of their readership. Thus, while the public may be more informed, they may be none the wiser. Indeed, the European context 
compares interestingly with that of the USA where consumers have been less aware of GM inputs into the food chain. In the USA, in the case of food additives such as soya, GM food technology has been less of an issue; at least until US GM exports were challenged in European markets (Jacobs, 1999). In an increasingly global market, food safety has become an integral part of the traded commodity, and global markets have served to raise general levels of awareness and concern.

\section{Why The Existed Models Of Consumer Behavior Can't Explain Food Consumption Internationally?}

Many behavioral theories, like theories about human needs, motivational processes, social comparison theory, social learning theory, theory of reasoned action and so on, all explain parts of the processes that determine consumer behaviour.

Throughout history our food consumption patterns have been changing continuously. Remarkable changes took place as regards the type of foods we eat (e.g. the introduction of the potato in Europe, the consumption of organ meat), the way we grow our food (e.g. the introduction of pesticides, bio-industry), how we process our food (e.g. frozen food, microwaves) and our table manners (e.g. the introduction of the fork in medieval Europe, fast food). All these changes more or less slowly conquered the food consumption habits of the masses, may it be in centuries (the use of the fork) or within a decade (the microwave). Many factors determine the speed and degree to which such changes diffuse through the population. Theory on the diffusion of innovation provides an inventory of the factors that affect the rate of adoption of this diffusion process. Moreover, this theory draws a perspective on consumer characteristics that determine if people are "innovators", or belong to the group of people that follow later in adopting a new practice.

An extensive review of the literature reveals that there is no simple framework that lends itself to a comprehensive study of consumer behavior in international markets. Problems with the existing frameworks make it essential to provide some structure to the study of consumer behavior across cultures. The Raju's model (1995) for consumption processes in developing economies, such as Eastern Europe, is considered in our study.

\section{Considering The Raju's A-B-C-D Paradigm For The Study}

Several comprehensive theories/models have been developed within the field of consumer behavior (Engel at al., 1968; Engel et al., 1995; Howard and Sheth, 1969; Nicosia, 1966). Models have also been developed for specific contexts, such as for family decision-making (Sheth, 1974) and information processing (Bettman, 1979). These theories/models have played an important role by detailing how various factors influence consumer behavior. However, the complexity of these models and the difficulties inherent in the operationalization of the numerous concepts has made their application in the international context especially difficult.

An extensive review of the literature reveals that there is no simple framework that lends itself to a comprehensive study of consumer behavior in international markets. Problems with the existing frameworks make it essential to provide some structure to the study of consumer behavior across cultures. Raju (1995) states that there are four sequential stages to represent the purchase and consumption processes in developing economies. These four stages are termed access, buying behavior, consumption characteristics, and disposal (with the acronym A-B-C-D). The A-B-C-D model provides a comprehensive framework for marketers to analyze consumer behavior findings (based on the particularities of Eastern Europe markets).

\section{Research On The Cross-Cultural Differences In Attitudes In Food Consumption Between Consumers From Developed And Developing Economies Of EU Member States: The Case Of Organic Food Consumption}

Research indicates that, while there is some evidence of cross-cultural differences in attitudes across different EU Member States (Gaskell et al., 2000; Gaskell et al., 1998; Saba et al., 1998; Schoderer et al., 1999), public perception of genetically-modified food across Europe tends to be negative. Genetically-modified food is associated with (unintended, particularly long term) risks for personal health and human health in general, risks to the environment, to future generations and to animal welfare. Genetic modification is seen as unnatural and unnecessary. 
An extra dimension not found with many other food safety issues is the presence of moral and ethical concerns influencing perception. There are concerns that the various sectors of the food industry will consider profit over and above safety. There is also some societal cynicism about the adequacy of current regulations, and a preference for accountable regulatory structures. Additionally, people want public consultation about biotechnology (Gaskell et al., 2000; Saba et al., 2000; Gaskell et al., 1998; Scholten et al., 1991; Frewer et al., 1994).

The attitudes of European consumers are not ubiquitously negative. For example, the public recognize the potential for benefits associated with genetically-modified food (Miles and Frewer, 2001). The acceptability of specific products is contingent on whether specific benefits are actually desired by consumers, and who is perceived to be the recipient of such benefits. For example, benefits related to consumer safety or health, the environment, animal welfare, or reduced cost is appreciated by consumers, and benefits for the food industry are not (Frewer et al., 1997; Frewer et al., 1996). There is evidence that information about potential benefits does improve consumer acceptance of genetically-modified food (Lusk et al., 2004; Rowe, 2004). Furthermore, for some people the absence of perceived benefits is enough to lead to rejection of genetically-modified food (Gaskell et al., 2004).

\section{HYPOTHESES \& RESEARCH MODEL}

We adopt the following definition for repurchase intention: "The consumer's judgment about buying again a designated food product from the same company, taking into accounts his or her current situation and likely circumstances" (Hellier et al., 2003).

Figure 1

The research model:

A Repurchase Intention Analysis for Technological Advanced Food Products in Developing Economies

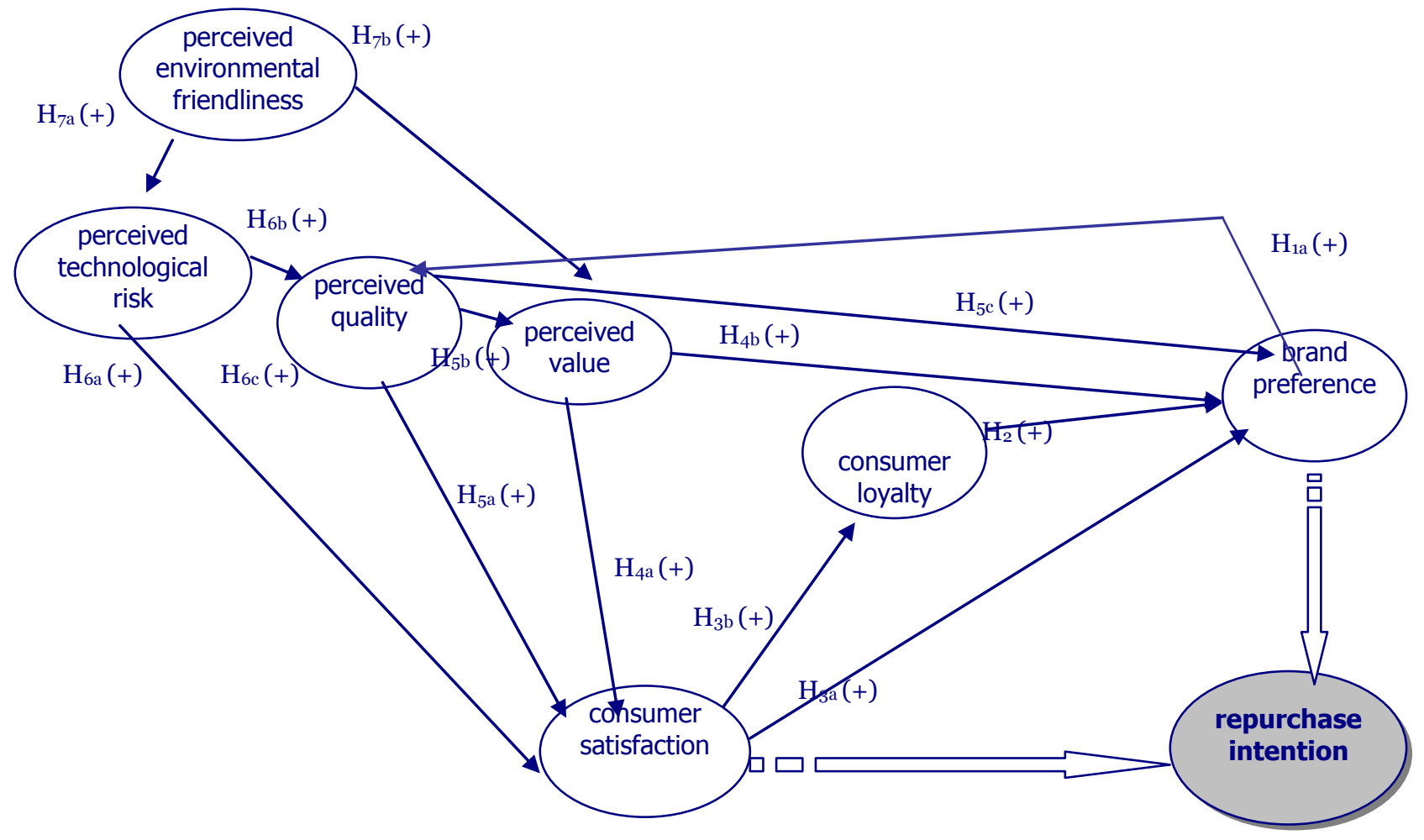


Figure 2

The structural model:

\begin{tabular}{|c|c|c|}
\hline Constructs & Definition & References \\
\hline $\begin{array}{l}\text { 1. Brand } \\
\text { preference }\end{array}$ & $\begin{array}{l}\text { The extent to which the consumer favors the designated } \\
\text { food product provided by his or her present food producer, } \\
\text { in comparison to the designated food products provided by } \\
\text { other food producers in his or her consideration set. }\end{array}$ & $\begin{array}{l}\text { Leuthesser et al. (1995); von Alvensleben } \\
\text { (1997) }\end{array}$ \\
\hline $\begin{array}{l}\text { 2. Consumer } \\
\text { loyalty }\end{array}$ & $\begin{array}{l}\text { The degree to which the consumer has exhibited, over } \\
\text { recent years, repeat purchase behavior of a particular food } \\
\text { producer; and the significance of that expenditure in terms } \\
\text { of the consumer's total outlay on the particular food } \\
\text { product. }\end{array}$ & Gannon and Sterling (2004) \\
\hline $\begin{array}{l}\text { 3. Consumer } \\
\text { satisfaction }\end{array}$ & $\begin{array}{l}\text { The degree of overall pleasure or contentment felt by the } \\
\text { consumer, resulting from the ability of the food product to } \\
\text { fulfill the consumer's desires, expectations and needs in } \\
\text { relation to the food product. }\end{array}$ & Mai and Ness (1999); Connor (1999) \\
\hline $\begin{array}{l}\text { 4. } \begin{array}{l}\text { Perceived } \\
\text { value }\end{array} \\
\text { valu }\end{array}$ & $\begin{array}{l}\text { The consumer's overall appraisal of the net worth of the } \\
\text { food product, based on the consumer's assessment of what } \\
\text { is received (benefits provided by the food product), and } \\
\text { what is given (costs or sacrifice in acquiring and utilizing } \\
\text { the food product). }\end{array}$ & $\begin{array}{l}\text { Frewer (1997); Steenkamp (1989); } \\
\text { Kyriakopoulos and Oude Ophuis (1997) }\end{array}$ \\
\hline $\begin{array}{l}\text { 5. Perceived } \\
\text { quality }\end{array}$ & $\begin{array}{l}\text { The consumer's overall assessment of food product's } \\
\text { attributes (cues are used by the consumer to evaluate the } \\
\text { performance of the food product). }\end{array}$ & $\begin{array}{l}\text { Becker (2000); Carlton and Perloff } \\
\text { (1994) }\end{array}$ \\
\hline $\begin{array}{l}\text { 6. } \begin{array}{l}\text { Perceived } \\
\text { technological } \\
\text { risk }\end{array} \\
\end{array}$ & $\begin{array}{l}\text { The consumer's overall assessment of possible negative } \\
\text { consequences of technological advancements in the food } \\
\text { product. }\end{array}$ & $\begin{array}{l}\text { Frewer and Shepherd (1998); Rozin et } \\
\text { al., (1986) }\end{array}$ \\
\hline $\begin{array}{l}\text { 7. Perceived } \\
\text { environmental } \\
\text { friendliness }\end{array}$ & $\begin{array}{l}\text { The consumer's overall assessment of the environmental } \\
\text { friendliness of the food product. }\end{array}$ & $\begin{array}{l}\text { Reijnders (2004); Szmigielski and } \\
\text { Sobiczewska (2000) }\end{array}$ \\
\hline
\end{tabular}

The basis of our research model is derived from the repurchase intention analysis by Hellier et al. (2003). The theoretical basis of the research model is derived from several sources. The model is developed from the satisfaction, attitude and intention relationships examined by Oliver $(1980,1981)$, from the analyses of consumers' understanding of genetic modification technology by Frewer et al., (1994), Miller and Huttner (1995) and Jones (1996) and from the analyses of consumers' understanding of products' environmental friendliness by Sriram and Forman (1993).

The research model is used to test the following hypotheses: $H 1(a)$.=The strength of brand preference has a direct positive effect on perceived quality. $H 2 .=$ Consumer loyalty has a direct positive effect on brand preference. $H 3(a)$. =Consumer satisfaction has a direct positive effect on brand preference. $H 3(b)=$ Consumer satisfaction has a direct positive effect on consumer loyalty to the food producer. $H 4(a)$.=Perceived value has a direct positive effect on consumer satisfaction. $H 4(b)$. =Perceived value has a direct positive effect on brand preference. $H 5(a)$. $=$ Perceived quality has a direct positive effect on consumer satisfaction. $H 5(b)=$ Perceived quality has a direct positive effect on perceived value. $H 5(c) .=$ Perceived quality has a direct positive effect on brand preference. $H 6(a)=$. Perceived technological risk has a direct positive effect on consumer satisfaction. $H 6(b) .=$ Perceived technological risk has a direct positive effect on perceived quality. $H 7(a)$.=Perceived environmental friendliness has not a direct positive effect on perceived technological risk. $H 7(b)$.=Perceived environmental friendliness has a direct positive effect on perceived value.

\section{Brand Preference Upon Perceived Quality}

Research works on the halo effect have revealed the causal relationship between attitudes towards a brand and the perceptions the individual has of the product sold under this brand (e.g. Leuthesser et al., 1995). Specifically, in the field of agro-food products, it has been proved that attitudes towards a brand may even effect the perception of 
the taste of food (von Alvensleben, 1997): HI(a).=The strength of brand preference has a direct positive effect on perceived quality.

\section{Consumer Loyalty Upon Brand Preference}

Consumers attempt to reduce the perceived risk by buying a well-known brand, seeking additional information and repeating the purchase of the brand that has provided satisfaction (Perry and Hamm, 1969; Roselius, 1971). The use of consumer loyalty segmentation in a firm's marketing strategy also increases the likelihood of a positive relationship between past patronage and present brand preference (Pritchard, 1991). The causal link between past repeat purchase and current brand preference may also be the result of consumer inertia (Roy et al., 1996): $H 2 .=$ Consumer loyalty has a direct positive effect on brand preference.

\section{Consumer Satisfaction Upon Brand Preference}

Consumer satisfaction can influence attitudinal change (e.g. food product and food supplier preference), which in turn affects repurchase intention (Innis, 1991; Oliver, 1980; Oliver and Bearden, 1985; Stauss and Neuhaus, 1997). A high level of satisfaction is likely to increase the probability that the brand in question will be retained in the consumer's consideration set and will increase the consumer's preference for the brand (Westbrook and Oliver, 1981): $H 3(a) .=$ Consumer satisfaction has a direct positive effect on brand preference.

\section{Consumer Satisfaction Upon Consumer Loyalty}

The positive relationship between consumer satisfaction and repurchase behavior has been challenged in the literature (Andreassen and Lindestad, 1998; Colgate et al., 1996; Fornell, 1992; Liljander and Strandvik, 1995; Srinvasan, 1996; Stauss and Neuhaus, 1997; Storbacka et al., 1994).

It has also been found that while dissatisfaction encourages switching, satisfaction does not ensure consumer commitment and loyalty (Danaher and Mattson, 1998; Heskett et al., 1994; Mittal and Lassar, 1998; Söderlund, 1998; Stum and Thiry, 1991). Bloemer and de Ruyter (1998) and Bloemer and Kasper (1995) have established that the positive relationship between satisfaction and loyalty is moderated by the extent to which consumers undertake brand expectation-performance comparisons: $H 3(b)=$.=Consumer satisfaction has a direct positive effect on consumer loyalty to the food producer.

\section{Perceived Value Upon Consumer Satisfaction}

Recently, conceptual frameworks have been developed that integrate consumer perceived value and consumer satisfaction (Liljander and Strandvik, 1995; Storbacka et al., 1994). To date, however, only a small number of studies have provided empirical evidence of the causal links between perceived value and satisfaction (Andreassen and Lindestad, 1998): H4(a).=Perceived value has a direct positive effect on consumer satisfaction.

\section{Perceived Value Upon Brand Preference}

The relationship between consumer's attitudes with respect to a generic product and the evaluations they carry out of a specific product is double. On the one hand, the models that estimate an individual's attitude towards a product according to his /her perceptions - weighted or not - regarding a set of relevant attributes are well known. On the other hand, the causal relationship between attitudes and evaluation may have the inverse direction. Thus, it is predictable that previous attitudes towards a product category may also affect the specific perceptions an individual obtains from a particular offer or brand (Sanzo et al. 2003): H4(b).=Perceived value has a direct positive effect on brand preference. 


\section{Perceived Quality Upon Consumer Satisfaction}

The literature has thoroughly tested the positive effect that perceptions about a product quality exercise on satisfaction (Anderson and Sullivan, 1993; Fornell et al., 1996; Spreng and Mckoy, 1996). The study of this relationship between perceived quality and satisfaction has been generally carried out in a global way so that the effects of the different perceived quality dimensions have not been analyzed separately. The individual consideration of these effects involves a more comprehensive knowledge and, consequently, it will allow improving the decisionmaking aimed at increasing consumer satisfaction. It seems reasonable to expect that each of the perceived quality dimensions will have a positive effect of different intensity on satisfaction. On the other hand, it is admissible that consumers may have different preferences with respect to which aspects of a product quality need to be improved, and, to what extent, to obtain a more satisfactory product.

Nevertheless, there exist certain factors that may affect quality perceptions and their relationship with satisfaction. Some of them, like affects and mood states, are receiving considerable attention in the literature. However, the effects of other possible elements related to previous attitudes towards a product category have not been sufficiently studied yet (Sanzo et al., 2003).: H5(a).=Perceived quality has a direct positive effect on consumer satisfaction.

\section{Perceived Quality Upon Perceived Value}

The listed types of quality, according to the product attribute approach are: a. search quality (quality attribute cues which become available at the time of shopping), and b. experience quality and c. credence quality. Although the concepts of search, experience, and credence quality are well established, their definition is ambiguous. In particular, the credence quality attributes sometimes are defined differently in the literature. Search and experience quality are both introduced by Nelson (1970), who was influenced from the optimal search literature and in particular by Stigler (1961). According to Nelson, shopping for a search quality good in several shops will increase the probability of finding a shop offering the good at a comparatively low price. The more shops are visited, the lower the expected best price available for the agent in one of the shops visited. In the case of experience goods, the agent has not only the usual search cost, but also the cost of testing the good. According to Nelson (1970), these costs have to be added: "Marginal cost will be different in the experience case from that of search ... the marginal cost of an experiment is the loss in utility from consuming a brand at random rather than using the best brand that one has already discovered". Regarding to the economic literature on credence quality goes back to Darby and Karni (1973), who introduced the following distinction among search, experience and credence quality: "We distinguish then three types of qualities associated with a particular purchase: search qualities which are known before purchase, experience qualities which are known costlessly only after purchase, and credence qualities, which are expensive to judge even after purchase". Relative to this concept is Anderson's and Philipsen's one (1998), who classify the quality features according to pre-purchase (pre-costs) and post-purchase (post-costs) of quality detection: $H 5(b)$.=Perceived quality has a direct positive effect on perceived value.

\section{Perceived Quality Upon Brand Preference}

A review of the literature reveals a fairly substantial number of studies dealing with various aspects of ownlabel shopping, including the assessment of the perceived quality of own-label products offered by the retailers (Senker, 1987; Ellis, 1988; Omar, 1992): H5(c).=Perceived quality has a direct positive effect on brand preference.

\section{Perceived Technological Risk Upon Consumer Satisfaction}

People tend to be suspicious of new technologies, often perceiving that the risks will outweigh the potential benefits, especially when the relative advantage of the technology is untested or unclear (Frewer and Shepherd, 1998). It is difficult to predict how consumers will accept new products and processes (Clarke and Moran, 1995). In situations where the public is relatively uninformed, public attitudes are often dependent on the type and level of media coverage (Miles and Frewer, 1999). Indeed, the popular press in particular has often plugged the information gap in some cases, some would argue, more with a view to selling copy than increasing the knowledge base of their 
readership. Thus, while the public may be more informed, they may be none the wiser. Indeed, the European context compares interestingly with that of the USA where consumers have been less aware of GM inputs into the food chain. In the USA, in the case of food additives such as soya, GM food technology has been less of an issue; at least until US GM exports were challenged in European markets (Jacobs, 1999). In an increasingly global market, food safety has become an integral part of the traded commodity, and global markets have served to raise general levels of awareness and concern: $H 6(a)$.=Perceived technological risk has a direct positive effect on consumer satisfaction.

\section{Perceived Technological Risk Upon Perceived Quality}

Theoretical frameworks have been put forward to explain how different factors interact to determine food product quality judgments. Perceptions of fresh food products' quality are likely to reflect the ways in which consumers' process information (Becker, 2000). According to the "perceived quality" approach certain cues are used by consumers to predict product quality attributes (Northen, 2000). Product attributes can be categorized according to whether they relate to the production process, including animal welfare and food safety issues or to specific product attributes associated with nutritional content, sensory factors, and product image (Caswell et al., 1998). Taking into consideration Holm's and MØhl's study (2000) about buying choices among relative meat products (determined by the way in which meat is produced and processed in modern agriculture and industry): $H 6(b) .=$ Perceived technological risk has a direct positive effect on perceived quality.

\section{Perceived Environmental Friendliness Upon Perceived Technological Risk}

Different factors affect perception of risk associated with various health-related and technological hazards (Drottz-Sjober, 1991). Societal risks (that is, risks which may be perceived as having widespread and generalized consequences should they occur) are perceived to have relatively low threat for the self, greater for other people, and greatest for society. This type of effect, where individuals believe that negative events are relatively unlikely to happen to them, has been termed "optimistic bias" by Weinstein (1986), (1987): H7(a).=Perceived environmental friendliness has not a direct positive effect on perceived technological risk.

\section{Perceived Environmental Friendliness Upon Perceived Value}

Reijnders study (2004) stress that food safety is a major public concern, especially in EU, following mishaps in the animal feed industry. These are associated with the handling of wastes. Financial gains to those responsible have been outweighed by economic losses. Reijnders study (2004) lists the safety risks, which include the presence of infectious bacteria and viruses, mycotoxins, additives, substances derived from packaging and conversion products originating in food processing. Present risks and presumable trends in food safety are highlighted in this study. Substantial improvement of food safety is possible. In part, such improvement is linked to environmental improvement, but there are also cases in which reductions in risk may increase the environmental burden of food supply. Improvement of food safety often entails increased costs. Major retailers and food producers apparently feel that consumers are willing to pay for substantially improved food safety: $H 7(b) .=$ Perceived environmental friendliness has a direct positive effect on perceived value.

\section{RESEARCH METHOD}

The major objective of this study is to test a model that explains consumer repurchase intention for technological advanced food products in developing economies. We address the core research themes of our study using a survey. Our intention is to test consumers' perceptions in order to investigate the potent influence of some set of variables, (discussed in the consumer research literature), in order to analyze repurchase intention for technological advanced food products in developing economies. The proposed model is not intended to explain all consumption behavior related to alternative food products. 


\section{Participants, Procedure \& Data Collection}

The stratified random sample (see Table 3) included 800 Greek households. The sample size was determined with the goal of obtaining at least 100 respondents from each of the eight (8) largest cities (Athens, Thessalonica, Patras, Larissa, Chania, Edessa, Volos and Agrinio). Our intention is to reach consumers with different experiences, attitudes and level of knowledge for technological advanced food products. Data was collected by means of face-toface interviews during the 8,5-week period. In total, 800 respondents (which were responsible for shopping meat products for their households) were asked to participate, and no one declined to take part to the study. Percent distribution of population by age groups has been considered (source: National Statistical Service of Greece).

A stratified random sample survey approach was adopted so that various subgroups according to the following contexts: a. decision-making and b. information processing were adequately represented in the sample. To ensure that respondents with reasonable experience of consuming meat products were included in the survey, 50 per cent of those selected for survey were consuming meat every day. Conversely, 50 per cent of those selected for survey were consuming meat once a week. The survey was stratified by sex, to control for an over or under-representation of respondents (58\% women and $42 \%$ men).

The response rate was $100 \%$. The participants in the study were 800 consumers, which were responsible for shopping meat products for their households. About fifty-eight $(57,8 \%)$ were women and about forty-two $(41,5 \%)$ were men. About nine (8,9\%) aged less than 20, about thirty-seven (37,3\%) aged 21-30, about twenty-two (22\%) aged 31-40, about sixteen (16,4\%) aged 41-50, about ten (10,3\%) aged 51-60, about five (5\%) aged more than 60. Fifty three per cent (53\%) were married and forty-seven per cent (47\%) were single. Thirty-four per cent (34\%) had a university/college degree and forty-eight per cent (48\%) were graduates of a high school and eighteen per cent (18\%) didn't graduate from a high school.

\section{Measures}

This study (Figure 1) is measuring seven (7) constructs: brand preference, consumer loyalty, consumer satisfaction, perceived value, perceived quality, perceived technological risk and perceived environmental friendliness. All constructs were measured using multiple items. All items were measured using a seven-point Likerttype scale (ranging from $1=$ strongly disagree to $7=$ strongly agree), in order to measure consumers' perceptions. The Appendix lists the variable questions constituting each factor measurement.

The construct and internal validity of each measurement scale is broadly supported by the research literature from which is it is derived. With establishing content validity, the questionnaire was refined through rigorous pretesting. The pre-testing was focused on instrument clarity, question wording, and validity. During the pre-testing, ten undergraduate students, three doctoral students, and three professors (of University of Ioannina) were invited to comment on the questions and wordings. The comments of these sixteen (16) individuals then provided a basis for revisions to the construct measures.

\section{Testing The Items}

The test of the validity of the items was based on a focus group methodology using the serial moderating technique (SMT).

Focus group methodology traditionally calls for an individual, trained moderator who personally elicits information in accord with some pre-defined purpose. The information is obtained from an assembled group, often comprised of six to 12 eligible participants. Group participants are selected to be sufficiently diverse to generate lively and innovative ideas, but sufficiently similar to bring common discourse to the session (Morgan, 1996). Participants of focus groups are also expected to convene only once (Zmud, 1988). Accordingly, participants are typically exposed to a single moderator or facilitator who engages one or several groups to discuss directed research topics. Since moderators vary in their training, personality and leadership styles, and interests, focus groups are open to moderator bias. 
In order to test the process, we advocate several moderators in succession over two classes of the Agribusiness Management Dept. of University of Ioannina, using moderately scheduled interviews (see Table 5). For the opening of the interviews, we have stated the purpose. The criterion for moderator selection included the following demographic criterion: "if students are raised to large urban centers, small towns, or villages". Previous focus group reviews (e.g. Fern, 1982; Morgan, 1996; Stewart and Shamdasami, 1990; Tynan and Drayton, 1988) have not considered this. For many marketing research projects resting on semi-structured and ill-structured problem domains that require alternative perspectives of multiple experts for both facilitating knowledge elicitation and verification (Grabowski et al., 1992), it would seem particularly appropriate.

For this pilot test, 3 moderator teams has been employed for time intervals that has been ranged from 20 to 40 minutes, sufficient to cover major sections of the overall focus interview guide (see Table 4). This overall guide was the joint product of all participating moderators.

The above process was prerequisite, in order to secure the success of the set of interviews (with focus groups) in Athens. The groups were structured according to the following demographic criteria: (a) where they are raised (urban centers, small towns, villages), (b) educational background (no education, high school, universities/colleges), (c) age (20-30, 31-41, 42-52, 53-63).

Table 1

The Items For The Seven Constructs

\begin{tabular}{|c|c|c|}
\hline Constructs & Items & Variables \\
\hline brand preference & $\begin{array}{l}\text { BP1=company name } \\
\text { BP2=product category attributes } \\
\text { BP3=consumer's emotional involvement } \\
\text { BP4=influences from family and friends }\end{array}$ & $\begin{array}{l}\text { (1) } \\
(2) \\
(3) \\
(4)\end{array}$ \\
\hline consumer loyalty & $\begin{array}{l}\text { CL1=consumer's inertia } \\
\text { CL2=reduction of perceived risk by buying a well-known brand } \\
\text { CL3=repurchase behavior }\end{array}$ & $\begin{array}{l}(5) \\
(6) \\
(7)\end{array}$ \\
\hline consumer satisfaction & $\begin{array}{l}\mathrm{CS} 1=\text { retained in consumer's consideration set } \\
\mathrm{CS} 2=\text { result of brand expectation-performance comparisons } \\
\mathrm{CS} 3=\text { repurchase intention }\end{array}$ & $\begin{array}{l}(8) \\
(9) \\
(10)\end{array}$ \\
\hline perceived value & $\begin{array}{l}\text { PV1=health advantages } \\
\text { PV2=taste } \\
\text { PV3=user convenience } \\
\text { PV4=competitive price } \\
\text { PV5=design of the product }\end{array}$ & $\begin{array}{l}(11) \\
(12) \\
(13) \\
(14) \\
(15)\end{array}$ \\
\hline perceived quality & $\begin{array}{l}\text { PQ1 }=\text { credence quality } \\
\text { PQ2= search quality } \\
\text { PQ3=experience quality }\end{array}$ & $\begin{array}{l}(16) \\
(17) \\
(18)\end{array}$ \\
\hline perceived technological risk & PTR1=way that the food product it is produced & (19) \\
\hline Perceived environmental friendliness & PEF1=packaging and food processing processes & $(20)$ \\
\hline
\end{tabular}

\section{FINDINGS}

\section{Sample Characteristics}

The response rate was $100 \%$. The participants in the study were 800 consumers, which were responsible for shopping meat products for their households. About fifty-eight $(57,8 \%)$ were women and about forty-two $(41,5 \%)$ were men. About nine $(8,9 \%)$ aged less than 20 , about thirty-seven $(37,3 \%)$ aged $21-30$, about twenty-two (22\%) aged 31-40, about sixteen (16,4\%) aged 41-50, about ten (10,3\%) aged 51-60, about five (5\%) aged more than 60. Fifty three per cent (53\%) were married and forty-seven per cent (47\%) were single. Thirty-four per cent (34\%) had a university/college degree and forty-eight per cent (48\%) were graduates of a high school and eighteen per cent (18\%) didn't graduate from a high school. 


\section{Descriptive Statistics}

Characteristics of the distributions of the answers were obtained by calculating means and standard deviations (see Table 7) for each item. The largest standard deviations (2,27, 2,24, 2,22 2,20 , 2,11, 2,01 , 2,01 , 2,00 ) were found in relation to items $16,14,4,5,13,19,20,7$. These items deal with: a. credence quality, $b$. competitive price, $c$. influences from family and friends, $d$. consumer's inertia, e. user convenience, $f$. way that the food product it is produced, g. packaging and food processing processes and $h$. repurchase behavior.

\section{Comparisons Among The Independent Groups}

Results based on Mann-Witney U test, show us that there are no significant statistical differences, for the grouping variable: "gender" (see Table 8). Results based on Kruskal Wallis test, show us that there are significant statistical differences for the grouping variable: "age" (see Table 9). Results based on Kruskal Wallis test, show us that there are significant statistical differences for the grouping variable: "educational background" (see Table 10). Results based on Kruskal Wallis test, show us that there are significant statistical differences for the grouping variable : "place of adobe" (see Table 11).

\section{Research Results}

Table 2

Research Results

\begin{tabular}{|c|c|c|c|c|c|}
\hline & \multirow[b]{2}{*}{ Hypothesis } & \multicolumn{3}{|c|}{ Inter-item Correlations } & \multirow[b]{2}{*}{ Comments } \\
\hline & & Relations & $\begin{array}{c}\text { Pearson } \\
\text { Correlations }\end{array}$ & Total $\mathbf{N}=\mathbf{8 0 0}$ & \\
\hline$H 1(a)$. & $\begin{array}{l}\text { The strength of brand } \\
\text { preference has a direct } \\
\text { positive effect on } \\
\text { perceived quality. }\end{array}$ & $\begin{array}{l}\mathrm{BP} 1 \rightarrow \mathrm{PQ} 1 \\
\mathrm{BP} 1 \rightarrow \mathrm{PQ} 2 \\
\mathrm{BP} 1 \rightarrow \mathrm{PQ} 3 \\
\mathrm{BP} 2 \rightarrow \mathrm{PQ} 1 \\
\mathrm{BP} 2 \rightarrow \mathrm{PQ} 2 \\
\mathrm{BP} 2 \rightarrow \mathrm{PQ} 3 \\
\mathrm{BP} 3 \rightarrow \mathrm{PQ} 2 \\
\mathrm{BP} 3 \rightarrow \mathrm{PQ} 3\end{array}$ & $\begin{array}{l}, 171 * * \\
, 183 * * \\
, 272 * * \\
, 149 * * \\
, 146 * * \\
, 167 * * \\
-, 122 * * \\
-, 103 * *\end{array}$ & $\begin{array}{l}(\mathrm{n}=797) \\
(\mathrm{n}=796) \\
(\mathrm{n}=797) \\
(\mathrm{n}=794) \\
(\mathrm{n}=793) \\
(\mathrm{n}=794) \\
(\mathrm{n}=797) \\
(\mathrm{n}=798)\end{array}$ & $\begin{array}{l}\text { BP1, BP2 and BP3 (except } \\
\text { BP4) have the most significant } \\
\text { effect on PQ items, so we accept } \\
\text { the hypothesis, as the chi- } \\
\text { squared values of inter-item } \\
\text { correlations are significant at the } \\
5 \% \text { level. }\end{array}$ \\
\hline$H 2$. & $\begin{array}{l}\text { Consumer loyalty has a } \\
\text { direct positive effect on } \\
\text { brand preference. }\end{array}$ & $\begin{array}{l}\mathrm{CL} 1 \rightarrow \mathrm{BP} 3 \\
\mathrm{CL} 1 \rightarrow \mathrm{BP} 4 \\
\mathrm{CL} 2 \rightarrow \mathrm{BP} 1 \\
\mathrm{CL} 2 \rightarrow \mathrm{BP} 2 \\
\mathrm{CL} 3 \rightarrow \mathrm{BP} 1 \\
\mathrm{CL} 3 \rightarrow \mathrm{BP} 4\end{array}$ & $\begin{array}{l}214 * * \\
, 129 * * \\
116 * * \\
, 162 * * \\
, 078 * \\
, 116 * * \\
\end{array}$ & $\begin{array}{l}(\mathrm{n}=796) \\
(\mathrm{n}=796) \\
(\mathrm{n}=799) \\
(\mathrm{n}=795) \\
(\mathrm{n}=796) \\
(\mathrm{n}=797)\end{array}$ & $\begin{array}{l}\text { we accept the hypothesis, as the } \\
\text { chi-squared values of inter-item } \\
\text { correlations are significant at the } \\
5 \% \text { level. }\end{array}$ \\
\hline$H 3(a)$. & $\begin{array}{l}\text { Consumer satisfaction } \\
\text { has a direct positive } \\
\text { effect on brand } \\
\text { preference. }\end{array}$ & $\begin{array}{l}\mathrm{CS} 1 \rightarrow \mathrm{BP} 1 \\
\mathrm{CS} 1 \rightarrow \mathrm{BP} 2 \\
\mathrm{CS} 1 \rightarrow \mathrm{BP} 3 \\
\mathrm{CS} 2 \rightarrow \mathrm{BP} 1 \\
\mathrm{CS} 2 \rightarrow \mathrm{BP} 2 \\
\mathrm{CS} 2 \rightarrow \mathrm{BP} 3 \\
\mathrm{CS} 3 \rightarrow \mathrm{BP} 1 \\
\mathrm{CS} 3 \rightarrow \mathrm{BP} 2 \\
\mathrm{CS} 3 \rightarrow \mathrm{BP} 3 \\
\mathrm{CS} 3 \rightarrow \mathrm{BP} 4\end{array}$ & $\begin{array}{c}, 208 * * \\
, 158 * * \\
-, 164 * * \\
, 200 * * \\
, 190 * * \\
-, 112 * * \\
, 202 * * \\
, 153 * * \\
-, 121 * * \\
-, 055\end{array}$ & $\begin{array}{l}(\mathrm{n}=797) \\
(\mathrm{n}=794) \\
(\mathrm{n}=793) \\
(\mathrm{n}=796) \\
(\mathrm{n}=797) \\
(\mathrm{n}=796) \\
(\mathrm{n}=798) \\
(\mathrm{n}=795) \\
(\mathrm{n}=799) \\
(\mathrm{n}=799)\end{array}$ & $\begin{array}{l}\text { we accept the hypothesis, as the } \\
\text { chi-squared values of inter-item } \\
\text { correlations are significant at the } \\
5 \% \text { level. }\end{array}$ \\
\hline$H 3(b)$. & $\begin{array}{l}\text { Consumer satisfaction } \\
\text { has a direct positive } \\
\text { effect on consumer } \\
\text { loyalty to the food } \\
\text { producer. }\end{array}$ & $\begin{array}{l}\mathrm{CS} 1 \rightarrow \mathrm{CL} 1 \\
\mathrm{CS} 1 \rightarrow \mathrm{CL} 2 \\
\mathrm{CS} 1 \rightarrow \mathrm{CL} 3 \\
\mathrm{CS} 2 \rightarrow \mathrm{CL} 1 \\
\mathrm{CS} 2 \rightarrow \mathrm{CL} 2 \\
\mathrm{CS} 2 \rightarrow \mathrm{CL} 3\end{array}$ & $\begin{array}{l}-, 022 \\
, 197 * * \\
, 273 * * \\
-, 032 \\
, 170 * * \\
, 117 * * \\
\end{array}$ & $\begin{array}{l}(\mathrm{n}=796) \\
(\mathrm{n}=799) \\
(\mathrm{n}=797) \\
(\mathrm{n}=795) \\
(\mathrm{n}=798) \\
(\mathrm{n}=796)\end{array}$ & $\begin{array}{l}\text { we accept the hypothesis, as the } \\
\text { chi-squared values of inter-item } \\
\text { correlations are significant at the } \\
5 \% \text { level. }\end{array}$ \\
\hline
\end{tabular}




\begin{tabular}{|c|c|c|c|c|c|}
\hline & & $\begin{array}{l}\mathrm{CS} 3 \rightarrow \mathrm{CL} 1 \\
\mathrm{CS} 3 \rightarrow \mathrm{CL} 2 \\
\mathrm{CS} 3 \rightarrow \mathrm{CL} 3\end{array}$ & $\begin{array}{l}-, 051 \\
, 115^{* *} \\
, 148^{* *}\end{array}$ & $\begin{array}{l}(n=797) \\
(n=800) \\
(n=798)\end{array}$ & \\
\hline$H 4(a)$. & $\begin{array}{l}\text { Perceived value has a } \\
\text { direct positive effect on } \\
\text { consumer satisfaction. }\end{array}$ & $\begin{array}{l}\mathrm{PV} 1 \rightarrow \mathrm{CS} 1 \\
\mathrm{PV} 1 \rightarrow \mathrm{CS} 2 \\
\mathrm{PV} 1 \rightarrow \mathrm{CS} 3 \\
\mathrm{PV} 2 \rightarrow \mathrm{CS} 1 \\
\mathrm{PV} 2 \rightarrow \mathrm{CS} 2 \\
\mathrm{PV} 2 \rightarrow \mathrm{CS} 3 \\
\mathrm{PV} 3 \rightarrow \mathrm{CS} 1 \\
\mathrm{PV} 3 \rightarrow \mathrm{CS} 2 \\
\mathrm{PV} 5 \rightarrow \mathrm{CS} 1 \\
\mathrm{PV} 5 \rightarrow \mathrm{CS} 2 \\
\mathrm{PV} 5 \rightarrow \mathrm{CS} 3\end{array}$ & $\begin{array}{l}, 190 * * \\
, 185 * * \\
, 242 * * \\
, 315 * * \\
, 189 * * \\
, 354 * * \\
, 094 * * \\
, 138 * * \\
-, 147 * * \\
-, 074 * \\
-, 158 * *\end{array}$ & $\begin{array}{l}(\mathrm{n}=799) \\
(\mathrm{n}=798) \\
(\mathrm{n}=800) \\
(\mathrm{n}=799) \\
(\mathrm{n}=798) \\
(\mathrm{n}=800) \\
(\mathrm{n}=798) \\
(\mathrm{n}=797) \\
(\mathrm{n}=795) \\
(\mathrm{n}=794) \\
(\mathrm{n}=796)\end{array}$ & $\begin{array}{l}\text { PV1, PV2, PV3 and PV5 (except } \\
\text { PV4) have the most significant } \\
\text { effect on CS items, so we accept } \\
\text { the hypothesis, as the chi- } \\
\text { squared values of inter-item } \\
\text { correlations are significant at the } \\
5 \% \text { level. }\end{array}$ \\
\hline$H 4(b)$ & $\begin{array}{l}\text { Perceived value has a } \\
\text { direct positive effect on } \\
\text { brand preference. }\end{array}$ & $\begin{array}{l}\mathrm{PV} 1 \rightarrow \mathrm{BP} 1 \\
\mathrm{PV} 1 \rightarrow \mathrm{BP} 2 \\
\mathrm{PV} 1 \rightarrow \mathrm{BP} 3 \\
\mathrm{PV} 2 \rightarrow \mathrm{BP} 1 \\
\mathrm{PV} 2 \rightarrow \mathrm{BP} 2 \\
\mathrm{PV} 2 \rightarrow \mathrm{BP} 3 \\
\mathrm{PV} 3 \rightarrow \mathrm{BP} 2 \\
\mathrm{PV} 3 \rightarrow \mathrm{BP} 3 \\
\mathrm{PV} 5 \rightarrow \mathrm{BP} 1 \\
\mathrm{PV} 5 \rightarrow \mathrm{BP} 3 \\
\mathrm{PV} 5 \rightarrow \mathrm{BP} 4\end{array}$ & $\begin{array}{c}, 231 * * \\
, 086 * \\
-, 071 * \\
, 091 * \\
, 138 * * \\
-, 073 * \\
, 085 * \\
, 178 * * \\
-, 086 * \\
, 299 * * \\
, 113 * *\end{array}$ & $\begin{array}{l}(\mathrm{n}=798) \\
(\mathrm{n}=795) \\
(\mathrm{n}=799) \\
(\mathrm{n}=798) \\
(\mathrm{n}=795) \\
(\mathrm{n}=799) \\
(\mathrm{n}=794) \\
(\mathrm{n}=798) \\
(\mathrm{n}=794) \\
(\mathrm{n}=795) \\
(\mathrm{n}=795)\end{array}$ & $\begin{array}{l}\text { PV1, PV2, PV3 and PV5 (except } \\
\text { PV4) have the most significant } \\
\text { effect on BP items, so we accept } \\
\text { the hypothesis, as the chi- } \\
\text { squared values of inter-item } \\
\text { correlations are significant at the } \\
5 \% \text { level. }\end{array}$ \\
\hline$H 5(a)$. & $\begin{array}{l}\text { Perceived quality has a } \\
\text { direct positive effect on } \\
\text { consumer satisfaction. }\end{array}$ & $\begin{array}{l}\mathrm{PQ} 1 \rightarrow \mathrm{CS} 1 \\
\mathrm{PQ} 1 \rightarrow \mathrm{CS} 2 \\
\mathrm{PQ} 1 \rightarrow \mathrm{CS} 3 \\
\mathrm{PQ} 2 \rightarrow \mathrm{CS} 1 \\
\mathrm{PQ} 2 \rightarrow \mathrm{CS} 2 \\
\mathrm{PQ} 2 \rightarrow \mathrm{CS} 3 \\
\mathrm{PQ} 3 \rightarrow \mathrm{CS} 1 \\
\mathrm{PQ} 3 \rightarrow \mathrm{CS} 2 \\
\mathrm{PQ} 3 \rightarrow \mathrm{CS} 3\end{array}$ & $\begin{array}{l}, 099 * * \\
, 178 * * \\
, 137 * * \\
, 173 * * \\
, 162 * * \\
, 167 * * \\
, 406 * * \\
, 343 * * \\
, 350 * *\end{array}$ & $\begin{array}{l}(\mathrm{n}=798) \\
(\mathrm{n}=797) \\
(\mathrm{n}=799) \\
(\mathrm{n}=797) \\
(\mathrm{n}=796) \\
(\mathrm{n}=798) \\
(\mathrm{n}=798) \\
(\mathrm{n}=797) \\
(\mathrm{n}=799)\end{array}$ & $\begin{array}{l}\text { we accept the hypothesis, as the } \\
\text { chi-squared values of inter-item } \\
\text { correlations are significant at the } \\
5 \% \text { level. }\end{array}$ \\
\hline$H 5(b)$. & $\begin{array}{l}\text { Perceived quality has a } \\
\text { direct positive effect on } \\
\text { perceived value. }\end{array}$ & $\begin{array}{l}\mathrm{PQ} 2 \rightarrow \mathrm{PV} 1 \\
\mathrm{PQ} 2 \rightarrow \mathrm{PV} 2 \\
\mathrm{PQ} 2 \rightarrow \mathrm{PV} 4 \\
\mathrm{PQ} 2 \rightarrow \mathrm{PV} 5 \\
\mathrm{PQ} 3 \rightarrow \mathrm{PV} 1 \\
\mathrm{PQ} 3 \rightarrow \mathrm{PV} 2 \\
\mathrm{PQ} 3 \rightarrow \mathrm{PV} 5\end{array}$ & $\begin{array}{c}, 221 * * \\
, 085 * \\
-, 092 * * \\
-, 038 \\
, 203 * * \\
, 161 * * \\
-, 098 * *\end{array}$ & $\begin{array}{l}(\mathrm{n}=798) \\
(\mathrm{n}=798) \\
(\mathrm{n}=798) \\
(\mathrm{n}=794) \\
(\mathrm{n}=799) \\
(\mathrm{n}=799) \\
(\mathrm{n}=795)\end{array}$ & $\begin{array}{l}\text { PQ2 and PQ3 (except PQ1) have } \\
\text { the most significant effect on PV } \\
\text { items, so we accept the } \\
\text { hypothesis, as the chi-squared } \\
\text { values of inter-item correlations } \\
\text { are significant at the } 5 \% \text { level. }\end{array}$ \\
\hline$H 5(c)$ & $\begin{array}{l}\text { Perceived quality has a } \\
\text { direct positive effect on } \\
\text { brand preference. }\end{array}$ & $\begin{array}{l}\mathrm{PQ} 1 \rightarrow \mathrm{BP} 1 \\
\mathrm{PQ} 1 \rightarrow \mathrm{BP} 2 \\
\mathrm{PQ} 1 \rightarrow \mathrm{BP} 3 \\
\mathrm{PQ} 2 \rightarrow \mathrm{BP} 1 \\
\mathrm{PQ} 2 \rightarrow \mathrm{BP} 2 \\
\mathrm{PQ} 2 \rightarrow \mathrm{BP} 3 \\
\mathrm{PQ} 2 \rightarrow \mathrm{BP} 4 \\
\mathrm{PQ} 3 \rightarrow \mathrm{BP} 1 \\
\mathrm{PQ} 3 \rightarrow \mathrm{BP} 2 \\
\mathrm{PQ} 3 \rightarrow \mathrm{BP} 3\end{array}$ & $\begin{array}{c}, 171 * * \\
, 149 * * \\
-, 060 \\
, 183 * * \\
, 146 * * \\
-, 122 * * \\
-, 068 \\
, 272 * * \\
, 167 * * \\
-, 103 * *\end{array}$ & $\begin{array}{l}(\mathrm{n}=797) \\
(\mathrm{n}=794) \\
(\mathrm{n}=798) \\
(\mathrm{n}=796) \\
(\mathrm{n}=792) \\
(\mathrm{n}=797) \\
(\mathrm{n}=797) \\
(\mathrm{n}=797) \\
(\mathrm{n}=794) \\
(\mathrm{n}=798)\end{array}$ & $\begin{array}{l}\text { we accept the hypothesis, as the } \\
\text { chi-squared values of inter-item } \\
\text { correlations are significant at the } \\
5 \% \text { level. }\end{array}$ \\
\hline$H 6(a)$ & $\begin{array}{l}\text { Perceived technological } \\
\text { risk has a direct positive } \\
\text { effect on consumer } \\
\text { satisfaction. }\end{array}$ & $\begin{array}{l}\text { PTR1 } \rightarrow \text { CS1 } \\
\text { PTR1 } \rightarrow \text { CS2P } \\
\text { TR } 1 \rightarrow \text { CS3 }\end{array}$ & $\begin{array}{l}, 227 * * \\
, 192 * * \\
, 209 * *\end{array}$ & $\begin{array}{l}(n=798) \\
(n=797) \\
(n=799)\end{array}$ & $\begin{array}{l}\text { we accept the hypothesis, as the } \\
\text { chi-squared values of inter-item } \\
\text { correlations are significant at the } \\
5 \% \text { level. }\end{array}$ \\
\hline
\end{tabular}




\begin{tabular}{|c|c|c|c|c|c|}
\hline$H 6(b)$. & $\begin{array}{l}\text { Perceived technological } \\
\text { risk has a direct positive } \\
\text { effect on perceived } \\
\text { quality. }\end{array}$ & $\begin{array}{l}\text { PTR } 1 \rightarrow \text { PQ1 } \\
\text { PTR1 } 1 \rightarrow \text { PQ2 } \\
\text { PTR } 1 \rightarrow \text { PQ3 }\end{array}$ & $\begin{array}{l}453 * * \\
, 401 * * \\
, 333 * *\end{array}$ & $\begin{array}{l}(n=798) \\
(n=797) \\
(n=798)\end{array}$ & $\begin{array}{l}\text { we accept the hypothesis, as the } \\
\text { chi-squared values of inter-item } \\
\text { correlations are significant at the } \\
5 \% \text { level. }\end{array}$ \\
\hline$H 7(a)$. & $\begin{array}{l}\text { Perceived } \\
\text { environmental } \\
\text { friendliness has not a } \\
\text { direct positive effect on } \\
\text { perceived technological } \\
\text { risk. }\end{array}$ & PEF1 $\rightarrow$ PTR 1 & ,490** & $(n=798)$ & $\begin{array}{l}\text { we accept the hypothesis, as the } \\
\text { chi-squared values of inter-item } \\
\text { correlations are significant at the } \\
5 \% \text { level. }\end{array}$ \\
\hline$H 7(b)$ & $\begin{array}{l}\text { Perceived } \\
\text { environmental } \\
\text { friendliness has a direct } \\
\text { positive effect on } \\
\text { perceived value. }\end{array}$ & $\begin{array}{l}\text { PEF1 } \rightarrow \text { PV1 } \\
\text { PEF1 } \rightarrow \text { PV2 } \\
\text { PEF1 } \rightarrow \text { PV3 } \\
\text { PEF } 1 \rightarrow \text { PV4 } \\
\text { PEF } 1 \rightarrow \text { PV5 }\end{array}$ & $\begin{array}{l}, 195 * * \\
-, 045 \\
-, 003 \\
-, 029 \\
-, 035\end{array}$ & $\begin{array}{l}(\mathrm{n}=800) \\
(\mathrm{n}=800) \\
(\mathrm{n}=799) \\
(\mathrm{n}=800) \\
(\mathrm{n}=796)\end{array}$ & the hypothesis is not accepted \\
\hline
\end{tabular}

** Correlation is significant at the 0.01 level (2-tailed).

* Correlation is significant at the 0.05 level (2-tailed).

Figure 3

\section{The Final Model}

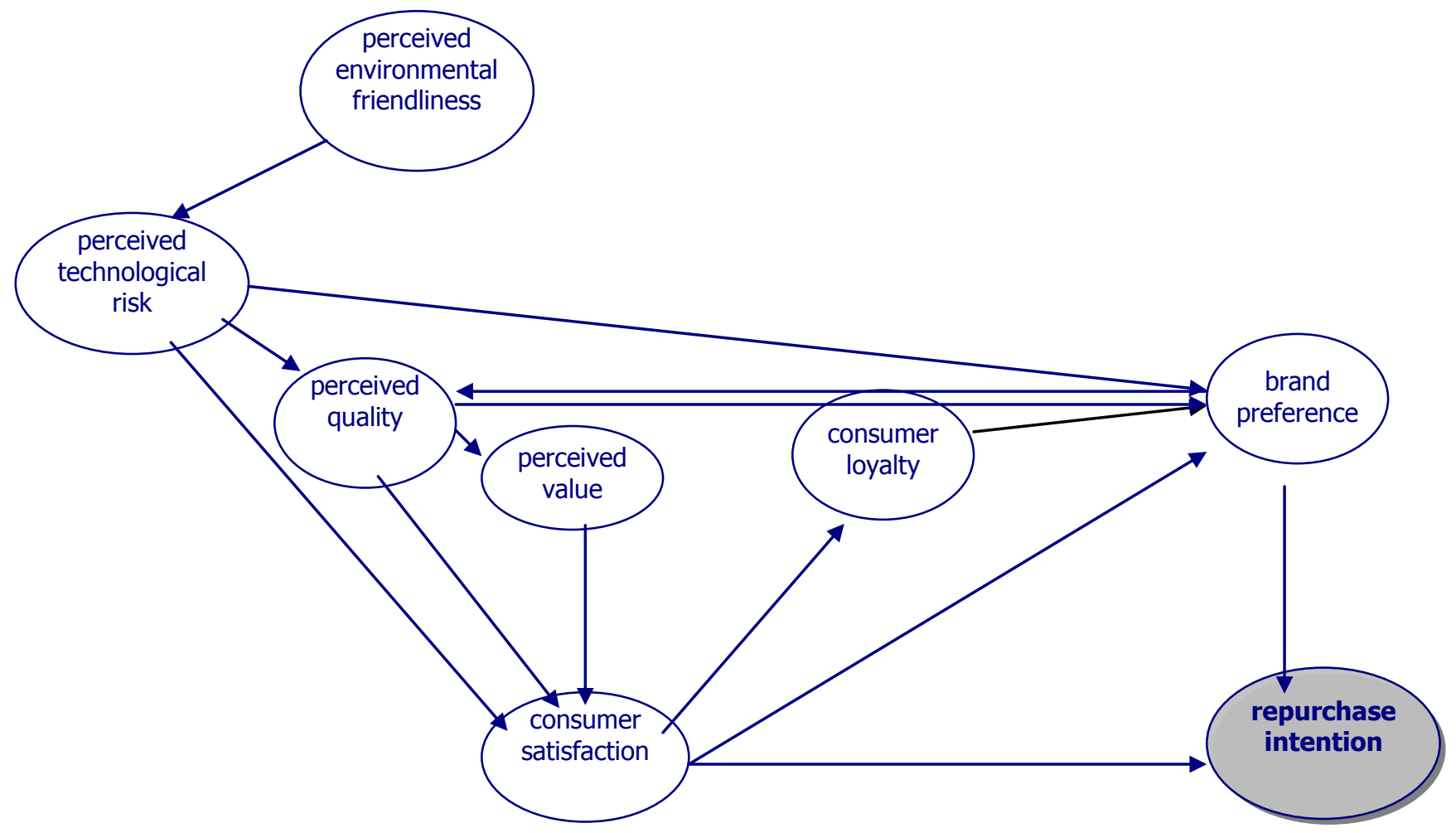




\section{DISCUSSION}

The major objective of this study was to test a model that explains consumer repurchase intention for technological advanced food products in developing economies. The following supports the arguments for the value of such a model: a. the series of evidence that the existing consumer behavior models and theories can't explain food consumption patterns, internationally and $b$. the major cross-cultural differences related perceptions for food products in EU member states.

The results from the statistical analysis show that perceived technological risk affect perceived quality, consumer satisfaction and brand preference. According to the final model, it seems that the construct of perceived technological risk is of high value in our discussion for the repurchase intention of technological advanced food products in developing economies. Search and experience quality items affect significantly perceived value of technological advanced food products. The results show that all perceived value items (health advantages, taste, user convenience and design of the products (except competitive price) affect brand preference and consumer satisfaction.

The results related to the high significant differences for the perceptions between consumers of large and small urban centers confirm Raju's A-B-C-D paradigm. The underlined model and a series of evidence on crosscultural differences in EU provide quite satisfactory arguments on consumer perception of food safety risk, which is varied from developed and developing economies. This means that the existing frameworks can't provide a comprehensive approach for food consumption internationally, so consumer behavior models must be developed under the prism of A-B-C-D paradigm.

Existing theories have played an important role by detailing how various factors influence consumer behavior. Throughout history our food consumption patterns have been changing continuously. Remarkable changes took place as regards the type of foods we eat (e.g. the introduction of the potato in Europe, the consumption of organ meat), the way we grow our food (e.g. the introduction of pesticides, bio-industry), how we process our food (e.g. frozen food, microwaves) and our table manners (e.g. the introduction of the fork in medieval Europe, fast food). All these changes more or less slowly conquered the food consumption habits of the masses, may it be in centuries (the use of the fork) or within a decade (the microwave). Many factors determine the speed and degree to which such changes diffuse through the population. Theory on the diffusion of innovation provides an inventory of the factors that affect the rate of adoption of this diffusion process. Moreover, this theory draws a perspective on consumer characteristics that determine if people are "innovators", or belong to the group of people that follow later in adopting a new practice.

\section{Marketing Implications}

This study provides valuable implications for international food companies wishing to enter eastern European markets and for eastern European food retailers. In contrast to the majority of cross-cultural consumer behavior studies that have used international student samples studying in developed economies (such as USA and UK), this study collected data from Greek consumers from large urban centers and very small towns in Greece. The final findings of our research can advance retailers' strategic tries as it seems that geographical differentiation is needed to be considered, in terms of pricing and promotion planning at a store level in developing countries.

Marketers should understand that food choice is often influenced more by the psychological interpretation of product properties than the physical properties of products themselves. Perception of food safety risk is one such psychological interpretation, which influences the attitudes and behavior of consumers with respect to the purchase of food products. Thus, perception of food safety risk has consequences for both consumer and producer welfare, and the overall effectiveness and efficiency of the food supply chain. This is especially the case where there is considerable divergence between what might be called objective, technical assessments of risk and subjective, psychological assessments of risk. Such divergence may arise because of inadequacy of risk communication systems, as usually happens in developing economies. 
Health advantages, taste, user convenience and the design of the product are significant issues that affect significantly brand preference and consumer satisfaction. In terms of behavioral pricing, this means that marketers should seriously reconsider the existing practices of pricing, as competitive price seems not be of high value for the consumers of these category of food products.

Search and experience quality issues related to the promotion at a store level are needed to be considered by marketers, as divergence may arise because of inadequacy of risk communication systems, as usually happens in developing economies.

\section{Further Research}

Further research is needed on building integrated models that can fully explains the trigger events that will affect behavioral pricing and promotion planning at a store level in developing economies.

\section{CONCLUSION}

The major objective of this study was to test a model that explains consumer repurchase intention for technological advanced food products in developing economies. We addressed the core research themes of our study using a survey of 800 Greek households. Our intention was to investigate the potent influence of some set of variables, (discussed in the consumer research literature), in order to analyze repurchase intention for technological advanced food products in developing economies. The proposed model is not intended to explain all consumption behavior related to alternative food products but the final findings of our research can advance retailers' strategic tries as it seems that geographical differentiation is needed to be considered in terms of marketing strategies in a store level.

\section{AKNOWLEDGMENTS}

We would like to thank Professor Ch. Fotopoulos for his contributory comments.

\section{REFERENCES}

1. Adams, J. (1998) A richter scale for risk? The scientific management of uncertainty versus the management of scientific uncertainty. Interdisciplinary Science Reviews 23, 2, 146-155.

2. Allen, C. T., Machleit, K. A., and Kleine, S. S. (1992) A comparison of attitudes and emotions as predictors of behavior at diverse levels of behavioral experience. Journal of Consumer Research 18 (March), 493-504.

3. Anderson, E. S. and Philipsen, K. (1998) The evolution of credence goods in customer markets: exchanging pigs and pokes.

4. Anderson, E. W. and Sullivan, M. W. (1993) The antecedents and consequences satisfaction for firms. Marketing Science 12, 2, 125-143.

5. Andreassen, T. W. and Lindestad, B. (1998) Customer loyalty and complex services. International Journal of Service Industry Management 9, 1, 7-23.

6. Barnett, J. and Breakwell, G. M. (2001) Risk perception and experience: hazard personality profiles and individual differences. Risk Analysis 21, 1, 171-177.

7. Baron, J., Hershey, J. C., and Kunreuther, H. (2000) Determinants of priority for risk reduction: the role of worry. Risk Analysis 20, 4, 413-427.

8. Bearden, W. O. and Teel, J. E. (1983) Selected determinants of consumer satisfaction and complaint reports. Journal of Marketing Research 20, (February), 21-28.

9. Becker, T. (2000) Consumer perception of fresh meat quality: a framework for analysis. British Food Journal 102, 3, 158-176.

10. Bettman, J. R. (1979) An Information Processing Theory of Consumer Choice. Reading: Addison-Wesley.

11. Bolton, R. N. and Drew, J. H. (1991) A multistage model of customers' assessments of service quality and value. Journal of Consumer Research 17, 4, 375-384.

12. Bloemer, J. M. M. and de Ruyter, K. (1998) On the relationship between store image, store satisfaction and store loyalty. European Journal of Marketing 32, 5/6, 499-513. 
13. Bloemenr, J. M. M. and Kasper, H. D. P. (1995) The complex relationship between consumer satisfaction and brand loyalty. Journal of Economic Psychology 16, 311-329.

14. Bolton, R. N. (1998) A dynamic model of the duration of the customer's relationship with a continuous service provider: the role of satisfaction. Marketing Science 17, 1, 45-65.

15. Boulding, W., Kalra, A., Staelin, R., and Zeithaml, V. A. (1993) A dynamic process model of service quality: from expectations to behavioral intentions. Journal of Marketing Research 30, 1, 7-27.

16. Bouyer, M., Bagdassarian, S., Chaabanne, S., and Mullet, E. (2001) Personally correlates of risk perception. Risk Analysis 21, 3, 457-465.

17. Brewer, M. S., Sprouls, G. K., and Russon, C. (1994) Consumer attitudes towards food safety issues. Journal of Food Safety 14, 63-76.

18. Buckland, R. (1997) Food for Our Future: Consumer IGD Research Report, www.foodfture.org.uk

19. Cadotte, E. R., Woodruff, R. B., and Jenkins, R. L. (1987) Expectations and norms in models of consumer satisfaction. Journal of marketing Research 24, 3, 305-314.

20. Caswell, J. A., Bredahl, M. E., and Hooker, N. H. (1998) How quality management metasystems are affecting the food industry. Review of Agricultural Economics 20, 547-557.

21. Clarke, J. and Moran, A. (1995) An investigation into the current market for fruit in the UK and the measures taken to promote an increase in consumer consumption. Nutrition \& Food Science, 95.

22. Colgate, M., Stewart, K., and Kinsella, R. (1996) Customer detection: a study of the student market in Ireland. International Journal of Bank Marketing 14, 3, 23-29.

23. Connor, R. (1999) Is healthy eating only for the young? Nutrition \& Food Science 99, 1, 12-18.

24. Danaher, P. and Mattsson, J. (1998) A comparison of service delivery processes of different complexity. International Journal of Service Industry Management 9, 1, 48-63.

25. Darby, M. R. and Karni, E. (1973) Free competition and the optimal amount of fraud. Journal of Law and Economics 16, 67-88.

26. Drottz-Sjoberg, B. M. (1991) Perception of Risk: Studies of Risk Attitudes, Perceptions and Definitions. Stockholm School of Economics Centre for Risk Research, Stockholm.

27. Ellis, K. (1988) An Investigation of private Label Purchase Behavior in the Packaged Grocery Market. Ph.D. thesis, London Business School.

28. Engel, J. F., Blackwell, R. D., and Miniard, P. W. (1995) Consumer Behavior, 8th. ed. New York: The Dryden Press.

29. Engel, J. F., Kollat, D. T., and Blackwell, R. D. (1968) Consumer Behavior. New York: Holt, Rinehart and Winston.

30. Fern, E. F. (1982) The use of focus groups for idea generation: the effects of group size, acquaintanceship and moderation on response quantity and quality. Journal of Marketing Research 19, 1, 1-13.

31. Fife-Schaw, C. and Rowe, G. (1996) Public perceptions of everyday food hazards: a psychometric study. Risk Analysis 16, 4, 487-500.

32. Fishbein, M. (1963) An investigation of the relationships between beliefs about an object and the attitude toward that object. Human Relations 16, 233-240.

33. Fishbein, M. and Middlestadt, S. E. (1997) A striking lack of evidence for non-belief-based attitude formation and change: a response to five commentaries. Journal of Consumer Psychology 6, 1, 107-114.

34. Ford, N. and Murphy, G. (1998) Managing environmental risks from genetically modified organisms: the role of safety training. Environmental Management and Health 9, 3.

35. Fornell, C. (1992) A national customer satisfaction barometer: the Swedish experience. Journal of Marketing $56,1,6-21$.

36. Fornell, C., Johnson, M. D., Anderson, E. W., Cha, J., and Bryant, B. E. (1996) The American customer satisfaction index: nature, purpose and findings. Journal of Marketing 60, (October), 7-18.

37. Frewer, L. (1997) Risk perception, social trust and public participation in strategic decision-making: implications for emerging technologies. Ambio 28, 6, 569-574.

38. Frewer, L., Howard, C., Hedderley, D., and Shepherd, R. (1997) Consumer attitudes towards different foodprocessing technologies used in cheese production: the influence of consumer benefit. Food Quality and Preference 8, 1, 1-10.

39. Frewer, L., Howard, C., and Shepherd, R. (1996) The influence of realistic product exposure on attitudes towards genetic engineering of food. Food Quality and Preference 7, 1, 61-67. 
40. Frewer, L., Howard, C., and Shepherd, R. (1998) Understanding public attitudes to technology. Journal of Risk Research 1, 3, 221-235.

41. Frewer, L. and Salter, B. (2002) Public attitudes, scientific advice and the politics of regulatory policy: the case of BSE. Science and Public Policy 29, 137-145.

42. Frewer, L. and Shepherd, R. (1998) Consumer perceptions of modern food biotechnology In Roller, S. and Harlander, S. Genetic Modification in the Food Industry. London: Blackie Academic and Professional.

43. Frewer, L., Shepherd, R., and Sparks, P. (1994) Biotechnology and food production: knowledge and perceived risk. British Food Journal 96, 9, 26-32.

44. Frewer, L. J., Shepherd, R., and Sparks, P. (1994) The interrelationship between knowledge, control and risk associated with a range of food-related hazards targeted at the individual, other people and society. Journal of Food Safety 14, 2, 19-40.

45. Gannon, B. and Sterling, J. (2004) Company culture provides competitive edge for Sargento Foods. Strategy and Leadership 32, 3, 31-35.

46. Gardner, M. P. (1985) Mood states and consumer behavior: a critical review. Journal of Consumer Research 9, (September), 132-140.

47. Gaskell, G., Allum, N., Bauer, M., Durant, J., Allansdottir, A., Bonfadelli, H., Boy, D., de Chaveigné, S., Fiaestad, B., Gutteling, J. M., Hampel, J., Jelsøe, E., Jesuino, J. C., Kohring, M., Kronberger, N., Midden, C., Nielsen, T. H., Przestalski, A., Rusanen, T., Sakellaris, G., and Torgersen, H. (2000) Biotechnology and the European public. Nature Biotechnology 18, 1, 935-938.

48. Gaskell, G., Allum, N., Wagner, W., Kronberger, N. Torgersen, H., Hampel, J., and Bardes, J. (2004) GM foods and the misperception of risk perception. Risk Analysis 24, 1, 185-194.

49. Gaskell, G., Bauer, M. W., and Durant, J. (1998) Public perceptions of biotechnology in 1996:

Eurobarometer 46.1. In Durant, J., Bauer, M. W., and Gaskell, G. Biotechnology in the Public Sphere: A European Sourcebook, Science Museum, London, 189-214.

50. Grabowski, M., Massey, A. P., and Wallace, W. A. (1992) Focus groups as a group knowledge acquisition technique. Knowledge Acquisition 4, 407-425.

51. Gregoriadis, L. (1999) GM food's overtake BSE as top safety concern, says survey. The Guardian.

52. Hellier, P. K., Geursen, G. M., Carr, R. A., and Rickard, J. A. (2003) Customer repurchase intention. A general structural equation model. European Journal of Marketing 37, 11/12, 1762-1800.

53. Heskett, J. L., Jones, T. O., Loveman, G. W., Sasser, W. E., Jr., and Schlesinger, L. A. (1994) Putting the service-profit chain to work. Harvard Business Review 72, 2, 164-174.

54. Holm, L. and MØhl, M. (2000) The role of meat in everyday food culture: an analysis of an interview study in Copenhagen. Appetite 34, 277-283.

55. Howard, J. A. and Sheth, J. N. (1969) The Theory of Buyer Behavior. New York: John Wiley \& Sons.

56. Innis, D. E. (1991) Customer service, repurchase intentions, market orientation and firm performance in the channel. Ohio State University.

57. Jacobs, P. (1999) Protest may mow down trend to alter crops; biotech: public outcry over genetically modified foods has the US agricultural industry backpedaling. The Los Angeles Times.

58. Jones, L. (1996) Food biotechnology: current developments and the need for awareness. Nutrition \& Food Science 96,6 .

59. Jones, T. O. and Sasser, W. E., Jr. (1995) Why satisfied customers defect. Harvard Business Review 73, 6, 88-99.

60. Kelley, S. W. and Hoffman, K. D. (1997) An investigation of positive affect prosocial behaviors and service quality. Journal of Retailing 73, 3, 407-427.

61. Kim, J., Lim, J-S., and Bhargava, M. (1998) The role of affect in attitude formation: a classical conditioning approach. Journal of the Academy of Marketing Science 26, 2, 143-152.

62. Kirk, S. F. L., Greenwood, D., Cade, J. E., and Pearman, A. D. (2002) Public perception of a range of potential food risks in the United Kingdom. Appetite 38, 189-197.

63. Kuznesof, S. and Ritson, C. (1996) Consumer acceptability of genetically modified foods with special reference to farmed salmon. British Food Journal 98, 4/5, 39-47.

64. Kyriakopoulos, K. and Oude Ophuis, P. A. M. (1997) A pre-purchase model of consumer choice for biological foodstuff. Journal of International Food \& Agribusiness Marketing 8, 4, 37-53. 
65. Kyriakopoulos, K. and van Dijk, G. (1997) Post purchase intention for organic foodstuff: a conceptual framework on the perception of product value. Journal of International Food \& Agri-Business Marketing 9, $3,1-19$.

66. Leuthesser, L., Kohli, C. S., and Harich, K. R. (1995) Brand equity: the halo effect measure. European Journal of Marketing 29, 4, 57-66.

67. Liljander, V. and Strandvik, T. (1995) The nature of customer relationships in services. In T. A. Swarz, D. E. Brown, and S. W. Brown. Advances in Services Marketing and Management, vol.4, JAI Press, Greenwich, CT, 141-167.

68. Lusk, J. L., House, L. O., Valli, C., Jaeger, S. R., Moore, M., Morrow, J. L., and Traill, W. B. (2004) Effect of information about benefits of biotechnology on consumer acceptance of genetic-modified food: evidence from experimental auctions in the United States, England and France. European Review of Agricultural Economics 31, 2, 179-204.

69. Lynch, J. G., Marmorstein, H., and Weigold, M. F. (1998) Choices from sets including remembered brands: use of recalled attributes and prior overall evaluations. Journal of Consumer Research 15 (September), 169184.

70. Mai, Li-Wei and Ness, M. R. (1999) Canonical correlation analysis of customer satisfaction and future purchase of mail-order specialty food. British Food Journal 101, 11, 857-870.

71. Marris, C., Langford, I., and O'Riordan, T. (1998) A quantitative test of the cultural theory of risk perceptions: comparison with the psychometric paradigm. Risk Analysis 18, 5, 635-647.

72. Marshall, S. (1994) Genetically modified organisms and food. Nutrition \& Food Science 96, 6.

73. Meloy, M. G. (2000) Mood-driven distortion of product information. Journal of Consumer Research 27 (December), 345-359.

74. Miles, S. and Frewer, L. (1999) Effective risk communication about food-related hazards: a review of the literature. Ministry of Agriculture (Project no. FS1844), Fisheries and Food, London.

75. Miles, S. and Frewer, L. (2001) Investigating specific concerns about different food hazards. Food Quality and Preference 12, 1, 47-61.

76. Miller, H. and Huttner, S. (1995) Food produced with new biotechnology: can labeling be anti-consumer? Journal of Public Policy \& Marketing 14, 2, 330-334.

77. Miniard, P. W. and Barone, M. J. (1997) The case for non-cognitive determinants of attitude: a critique of Fishbein and Middlestadt. Journal of Consumer Psychology 6, 1, 77-91.

78. Mittal, B. and Lassar, W. M. (1998) Why do customers switch? The dynamics of satisfaction versus loyalty. The Journal of Services Marketing 12, 3, 177-194.

79. Morgan, D. (1996) Focus groups. Annual Review of Sociology 22, 29-152.

80. Nelson, P. (1970) Information and consumer behavior. Journal of Political Economy 78, 311-329.

81. Nicosia, F. M. (1966) Consumer Decision Processes. Englewood Cliffs, NJ: Prentice-Hall.

82. Northen, J. R. (2000) Quality attributes and quality cues, effective communication in the UK meat supply chain. British Food Journal 102, 3, 230-245.

83. Nutrition on the Internet (NOI) (1999) Update on the GM foods issue. Nutrition \& Food Science 99, 4.

84. Nutrition on the Internet (NOI) (1999) Update on the GM foods issue. Nutrition \& Food Science 99, 6.

85. Oliver, R. L. (1980) A cognitive model of the antecedents and consequences of satisfaction decisions. Journal of Marketing Research 17 (November), 460-469.

86. Oliver, R. L. (1981) Measurement and evaluation of satisfaction processes in retail settings. Journal of Retailing 57, 3, 25-48.

87. Oliver, R. L. and Bearden, W. O. (1985) Disconfirmation processes and consumer evaluations in product usage. Journal of Business Research 13, 235-246.

88. Omar, O. E. (1992) Grocery Shopper Behavior and Retailers' Own-label Products. Ph.D. thesis, Manchester Metropolitan University.

89. Perry, M. and Hamm, B. C. (1969) Canonical analysis of relations between socio-economic risk and personal influence in purchase decisions. Journal of Marketing Research 6, 3, 351-354.

90. Pollack, A. (1999) A disputed study suggests possible harm from genetically altered food. New York Times.

91. Pritchard, M. P., (1991) Development of the psychological commitment instrument (PCI) for measuring travel service loyalty. University of Oregon. 
92. Raju, P. S. (1995) Consumer behavior in global markets: the A-B-C-D paradigm and its application to Eastern Europe and the Third World. Journal of Consumer Marketing 12, 5, 37-56.

93. Reijnders, L. (2004) Food safety, environmental improvement and economic efficiency in The Netherlands. British Food Journal 106, 5, 388-405.

94. Roselius, T. (1971) Consumer rankings of risk reduction methods. Journal of Marketing 35, $1,56-61$.

95. Rosenberg, M. J. (1960) An analysis of affective-cognitive consistency. In C. I. Hovland and M. J. Rosenberg (eds.) Attitude Organization and Change.

96. Rowe, G. (2004) How can genetically-modified foods be made publicly acceptable?. Trends in Biotechnology 22, 3, 107-109.

97. Rowe, G. and Wright, G. (2001) Differences in expert and lay judgments of risk: myth or reality?. Risk Analysis 21, 2, 341-356.

98. Roy, R., Chintagunta, P. K., and Haldar, S. (1996) A framework for investigating habits, 'the hands of the past,' and heterogeneity in dynamic brand choice. Marketing Science 15, 3, 280-299.

99. Rozin, P., Pelchat, M. L., and Fallon, A. E., (1986) Psychological factors influencing food choice. In C. Ritson, L. Gofton, and J. McKenzie, The Food Consumer, John Wiley \& Sons Ltd. Chichester and New York, 85-106.

100. Saba, A., Moles, A., and Frewer, L. (1998) Public concerns about general and specific applications of genetic engineering: a comparative study between the UK and Italy. Nutrition and Food Science 98, 1, 19-29.

101. Sanzo, M. J., Belen del Rio, A., Iglesias, V., and Vazquez, R. (2003) Attitude and satisfaction in a traditional food product. British Food Journal 105, 11, 771-790.

102. Scholderer, J., Balderiahn, I., Bredahl, L., and Grunert, G.K. (1999) The perceived risks and benefits of genetically-modified food products: expert versus consumers. In Dubois, B., Lowrev, T., Shrum, L. J., and Vanhuele, M. European Advances in Consumer Research, IV, Association of Consumer Research, Provo, UT, 123-129.

103. Scholten, A. H., Feenstra, M. H., and Hamstra, A. M. (1991) Public acceptance of foods from biotechnology. Food Biotechnology 5, 3, 331-345.

104. Senker, J. (1987) Technological co-operation between manufacturers and retailers to meet market demand. Food marketing 2, 3, 38.

105. Sheth, J. N. (1974) A theory of family buying decisions. In J. N. Sheth. Models of Buying Behavior, Harper \& Row, New York.

106. Söderlund, M. (1998) Customer satisfaction and its consequences on customer behaviour revisited. International Journal of Service Industry Management 9, 2, 169-188.

107. Sparks, P. and Shepherd, R. (1994) Public perceptions of the potential hazards associated with food production and food consumption: an empirical study. Risk Analysis 14, 5, 799-806.

108. Spreng, R. A. and Mackoy, R. D. (1996) An empirical examination of a model of perceived service quality and satisfaction. Journal of Retailing 72, 2, 201-214.

109. Srinivasan, M. (1996) New insights into switching behavior. Marketing Research 8, 3, $27-33$.

110. Sriram, V. and Forman, A. (1993) The Relative Importance of Product's Environmental Attributes: A Crosscultural Comparison. International Marketing Review 10, 3.

111. Stauss, B. and Neuhaus, P. (1997) The qualitative satisfaction model. International Journal of Service Industry Management 8, 3, 236-249.

112. Steenkamp, J. B. E. M. (1989) Product Quality: An Investigation into the Concept and How it is Perceived by Consumers. Maastricht: Van Gorcum Assen.

113. Stewart, D. W. and Shamdasani, P. N. (1990) Focus Groups. Theory and Practice. Applied Social Science Research Methods Series 20, 69-86.

114. Stigler, G. (1961) The economics of information. Journal of Political Economy 69, 213-225.

115. Storbacka, K., Strandvik, T., and Grönroos, C. (1994) managing customer relationships for profit: the dynamics of relationship quality. International Journal of Service Industry Management 5, 5, 21-38.

116. Stum, D. L. and Thiry, A. (1991) Building customer loyalty. Training and Development Journal, (April), 3436.

117. Szmigielski, S. and Sobiczewska, E. (2000) Cellular phone systems and human health - problems with risk perception and communication. Environmental Management and Health 11, 4, 352-368. 
118. Tomlison, M. (1994) Do Distinct Class Preferences for Foods Exist?: An Analysis of Class-based Tastes. British Food Journal 96, 7, 11-17.

119. Tynan, C. A. and Drayton, J. L. (1988) Conducting focus groups - a guide for first time users. Marketing Intelligence and Planning 6, 1, 5-9.

120. van der Pol, M. and Ryan, M. (1996) Using conjoint analysis to establish consumer preferences for fruit and vegetables $98,8,5-12$.

121. von Alvensleben, R. (1997) Consumer behaviour. In D. I. Padberg, C. Ritson, and L. M. Albisu, Agro-Food Marketing, Wallingford: CAB International.

122. Weinstein, N. D. (1986) Optimistic Bias in Public Perceptions of the Risk from Radon. American Journal of Public Health 78, 7, 769-800.

123. Weinstein, N. D. (1987) Unrealistic Optimism about Susceptibility to Health Problems: Conclusions from a Community-wide Sample. Journal of Behavioral Medicine 10, 5, 481-500.

124. Weiss, R. (1999) Gene-altered food study fuels a fire. The Washington Post.

125. Westbrook, R. A. and Oliver, R. L. (1981) Developing better measures of consumer satisfaction: some preliminary results. In Monroe, K.B. Advances in Consumer Research, vol. 8, Association for Consumer Research, Ann Arbor, MI, 94-99.

126. Woodside, A. G., Frey, L. L., and Daly, R. T. (1989) Linking service quality customer satisfaction and behavioral intention. Journal of Health Care Marketing 9, 4, 5-17.

127. Yeung, R. M. W. and Morris, J. (2001) Food safety risk: consumer perception and purchase behaviour. British Food Journal 103, 3, 170-186.

128. Zmud, R. W. (1988) Specification structure and measurement for the non-repeating group decision context. In R. M. Lee, A. M. Cosh, and P. Migliarese, Organizational Decision Support Systems, Amsterdam: Elsevier Science Publishers.

\section{APPENDIX}

Table 3

Sample's Socio-Demographic Profile ( $\mathrm{N}=800)$

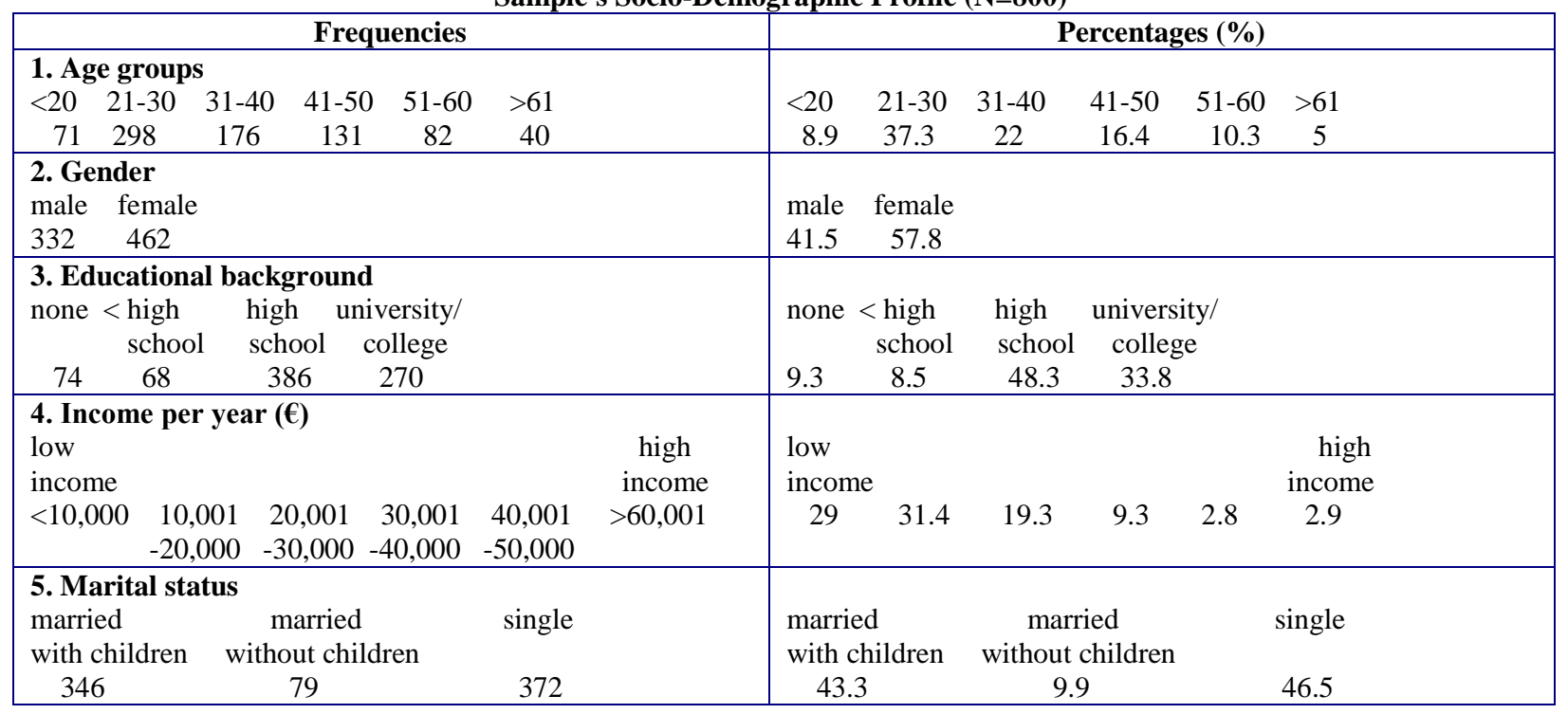


Table 4

Test Of Items With Focus Groups: Interview Guide

\begin{tabular}{|l}
\hline I. Brand Preference \\
\hline A. company name \\
B. product category attributes \\
C. consumer's emotional involvement \\
D. influences from family and friends
\end{tabular}

II. Consumer Loyalty

A. consumer's inertia

B. reduction of perceived risk by buying a well-known brand

C. repurchase behavior

\section{Consumer Satisfaction}

A. retained in consumer's consideration set

B. result of brand expectation-performance comparisons

C. repurchase intention

D. positive word-of-mouth

IV. Perceived Value

A. health advantages

B. taste

C. user convenience

D. competitive price

E. design of the product

V. Perceived Quality

A. hormones and antibiotics

B. reading the ingredients at the label

C. taste

D. color

E. smell

VI. Perceived Technological Risk

A. way that the food product it is produced

B. negative consequences of the technological advancements in foods

VII. Perceived Environmental Friendliness

A. packaging and food processing processes

B. corporate image of eco-sensitivity

Table 5

Test Of Items With Focus Groups: The Moderately Scheduled Interview

I. As a food consumer, what makes you most to prefer a brand?

A. What about the company name?

B. What about the product category attributes?

C. What about emotional involvement?

D. What about influences from family and friends?

II. As a food consumer, what loyalty to a brand means to you?

A. What about full trust to the food producer?

B. What about full satisfaction and buying the product again and again?

C. What about low risk?

III. As a food consumer, what satisfaction for a brand means to you?

A. What about keeping in mind the specific brand?

B. What about a positive opinion from the comparison between expectations and performance of the brand?

C. What about buying the brand again?

D. What recommending the brand to my family and friends?

IV. As a food consumer, what is valuable for you?

A. What about health advantages?

B. What about taste?

C. What about convenience?

D. What about low price?

E. What about the design of the product? 


\begin{tabular}{|l|}
\hline V. As a food consumer, what are your quality criteria? \\
\hline A. What about hormones and antibiotics? \\
B. What about the information listed at the package? \\
C. What about taste? \\
D. What about color? \\
E. What about smell? \\
\hline VI. As a food consumer, what are the risks that fear you? \\
\hline A. What about the way it is produced? \\
B. What about the negative consequences of biotechnology? \\
C. What about packaging? \\
D. What about food processing? \\
\hline
\end{tabular}

Table 6

Variable Questions For The Research Model Constructs

\begin{tabular}{|c|c|c|}
\hline Construct & Variable & Question \\
\hline \multirow[t]{4}{*}{$\begin{array}{l}\text { brand } \\
\text { preference }\end{array}$} & $\mathrm{BP} 1=$ company name & $\begin{array}{l}\text { (1) "My preference to the particular brand depends on the extent that my } \\
\text { requirements are satisfied by the particular company compared to the other } \\
\text { companies." }\end{array}$ \\
\hline & $\mathrm{BP} 2=$ product category attributes & $\begin{array}{l}\text { (2) "My preference to the particular brand depends on my attitudes to that } \\
\text { product category." }\end{array}$ \\
\hline & $\begin{array}{l}\text { BP3=consumer's emotional } \\
\text { involvement }\end{array}$ & $\begin{array}{l}\text { (3) "I prefer to repurchase the particular brand because of emotional } \\
\text { reasons." }\end{array}$ \\
\hline & $\begin{array}{l}\text { BP4=influences from family and } \\
\text { friends }\end{array}$ & $\begin{array}{l}\text { (4) "Family's and friends' influence is important to me on repurchasing the } \\
\text { particular brand." }\end{array}$ \\
\hline \multirow[t]{3}{*}{$\begin{array}{l}\text { consumer } \\
\text { loyalty }\end{array}$} & CL1=consumer's inertia & $\begin{array}{l}\text { (5) "I repurchase the particular brand because of my inertia to search for } \\
\text { other brands." }\end{array}$ \\
\hline & $\begin{array}{l}\text { CL2=reduction of perceived risk } \\
\text { by buying a well-known brand }\end{array}$ & $\begin{array}{l}\text { (6) "I prefer to repurchase the particular brand because I know it and I } \\
\text { minimize any potential risks." }\end{array}$ \\
\hline & CL3=repurchase behavior & $\begin{array}{l}\text { (7) "I repurchase the particular brand because of my specific preference to } \\
\text { it." }\end{array}$ \\
\hline \multirow[t]{3}{*}{$\begin{array}{l}\text { consumer } \\
\text { satisfaction }\end{array}$} & $\begin{array}{l}\text { CS1=retained in consumer's } \\
\text { consideration set }\end{array}$ & (8) "I always repurchase the particular brand when I am satisfied with it." \\
\hline & $\begin{array}{l}\text { CS2=result of brand } \\
\text { expectation-performance } \\
\text { comparisons }\end{array}$ & $\begin{array}{l}\text { (9) "Repurchasing the particular brand depends on the comparison between } \\
\text { brand expectation and its performance." }\end{array}$ \\
\hline & CS3=repurchase intention & (10) "I will repurchase the particular brand if I am totally satisfied with it." \\
\hline \multirow{5}{*}{$\begin{array}{l}\text { perceived } \\
\text { value }\end{array}$} & PV1=health advantages & (11) "I repurchase the particular brand because it is good to my health." \\
\hline & PV2=taste & (12) "I repurchase the particular brand because I like the taste." \\
\hline & PV3=user convenience & (13) "I repurchase the particular brand because its use is convenient to me." \\
\hline & PV4=competitive price & $\begin{array}{l}\text { (14) "I repurchase the particular brand because of its low price compared to } \\
\text { other brands." }\end{array}$ \\
\hline & PV5=design of the product & $\begin{array}{l}\text { (15)" I repurchase the particular brand because I like a lot its design (shape, } \\
\text { colour, size, etc.)." }\end{array}$ \\
\hline \multirow[t]{3}{*}{$\begin{array}{l}\text { perceived } \\
\text { quality }\end{array}$} & PQ1= credence quality & $\begin{array}{l}\text { (16) "When I am going to repurchase the particular brand I take into } \\
\text { serious consideration the intangible ingredients (such as hormones and } \\
\text { antibiotics) that contains." }\end{array}$ \\
\hline & PQ2=search quality & $\begin{array}{l}\text { (17) "When I am going to repurchase the particular brand I take into } \\
\text { serious consideration the available product information (i.e. label)." }\end{array}$ \\
\hline & PQ3=experience quality & $\begin{array}{l}\text { (18) "When I am going to repurchase the particular brand I take into } \\
\text { serious consideration my previous experience on this product." }\end{array}$ \\
\hline $\begin{array}{l}\text { perceived } \\
\text { technological } \\
\text { risk }\end{array}$ & $\begin{array}{l}\text { PTR } 1=\text { way that the food product } \\
\text { it is produced }\end{array}$ & $\begin{array}{l}\text { (19) "When I am going to repurchase the particular brand I take into } \\
\text { serious consideration the way that the product is produced and processed } \\
\text { (for example, use of antibiotics and hormones, animal welfare, hygiene } \\
\text { standards)." }\end{array}$ \\
\hline $\begin{array}{l}\text { perceived } \\
\text { environmental } \\
\text { friendliness }\end{array}$ & $\begin{array}{l}\text { PEF1=packaging and food } \\
\text { processing processes }\end{array}$ & $\begin{array}{l}\text { (20) "When I am going to repurchase the particular brand I take into } \\
\text { serious consideration the environmental friendliness of its production (i.e., } \\
\text { risk of environmental pollution, prudent use of natural resources)." }\end{array}$ \\
\hline
\end{tabular}


Table 7

Descriptive Statistics For The Items Of The Repurchase Intention

\begin{tabular}{|c|c|c|c|c|c|c|c|}
\hline & Items & $\mathbf{N}$ & Scale & Mean & $\begin{array}{c}\text { Std. } \\
\text { Deviation }\end{array}$ & Skewness & Kurtosis \\
\hline 1. & company name & 798 & 7 & 5,0777 & 1,85388 &,- 801 &,- 413 \\
\hline 2. & product category attributes & 795 & 7 & 4,8830 & 1,91577 &,- 645 &,- 663 \\
\hline 3. & consumer's emotional involvement & 799 & 7 & 2,4844 & 1,97907 & 1,032 &,- 346 \\
\hline 4. & influences from family and friends & 799 & 7 & 3,6421 & 2,22134 &, 150 & $-1,448$ \\
\hline 5. & consumer's inertia & 797 & 7 & 3,3287 & 2,20947 & , 428 & $-1,294$ \\
\hline 6. & $\begin{array}{l}\text { reduction of perceived risk by buying a well- } \\
\text { known brand }\end{array}$ & 800 & 7 & 5,1312 & 1,99097 &,- 939 &,- 365 \\
\hline 7. & repurchase behavior & 798 & 7 & 4,9035 & 2,00237 &,- 707 &,- 774 \\
\hline 8. & retained in consumer's consideration set & 799 & 7 & 6,1527 & 1,27997 & $-1,984$ & 4,021 \\
\hline 9. & $\begin{array}{l}\text { result of brand expectation-performance } \\
\text { comparisons }\end{array}$ & 798 & 7 & 5,7719 & 1,61490 & $-1,555$ & 1,688 \\
\hline 10. & repurchase intention & 800 & 7 & 6,2338 & 1,34680 & $-2,135$ & 4,281 \\
\hline 11. & health advantages & 800 & 7 & 5,3850 & 1,88114 &,- 968 &,- 159 \\
\hline 12. & taste & 800 & 7 & 5,8600 & 1,58542 & $-1,639$ & 2,076 \\
\hline 13. & user convenience & 799 & 7 & 4,2040 & 2,11740 &,- 241 & $-1,269$ \\
\hline 14. & competitive price & 800 & 7 & 4,3200 & 2,24865 &,- 278 & $-1,380$ \\
\hline 15. & design of the product & 796 & 7 & 3,0239 & 1,98502 &, 518 & $-1,014$ \\
\hline 16. & credence quality & 799 & 7 & 4,7084 & 2,27525 &,- 278 &,- 285 \\
\hline 17. & search quality & 798 & 7 & 5,2231 & 1,98940 &,- 899 &,- 447 \\
\hline 18. & experience quality & 799 & 7 & 5,7922 & 1,38263 & $-1,452$ & 1,982 \\
\hline 19. & way that the food product it is produced & 799 & 7 & 5,1940 & 2,01900 &,- 809 &,- 673 \\
\hline 20. & packaging and food processing processes & 800 & 7 & 4,8650 & 2,01975 &,- 591 &,- 902 \\
\hline & Valid N (listwise) & 773 & & & & & \\
\hline
\end{tabular}

Table 8

Comparisons Among The Independent Groups*

(Grouping Variable: Gender)

\begin{tabular}{|l|l|c|c|c|c|}
\hline & \multicolumn{1}{|c|}{ Items } & $\begin{array}{c}\text { Mann- } \\
\text { Whitney U }\end{array}$ & $\begin{array}{c}\text { Wilcoxon } \\
\text { W }\end{array}$ & $\begin{array}{c}\text { Z } \\
\text { (2-tailed) }\end{array}$ \\
\hline 1. & company name & 72139,500 & 126754,500 & $-1,317$ &, 188 \\
\hline 2. & product category attributes & 68152,000 & 122767,000 & $-2,445$ &, 014 \\
\hline 3. & consumer's emotional involvement & 76233,000 & 182724,000 &,- 101 &, 920 \\
\hline 4. & influences from family and friends & 74331,500 & 129609,500 &,- 702 &, 483 \\
\hline 5. & consumer's inertia & 75488,500 & 181518,500 &,- 207 &, 836 \\
\hline 6. & reduction of perceived risk by buying a well- & 72010,000 & 127288,000 & $-1,510$ &, 131 \\
& known brand & & &,- 382 &, 703 \\
\hline 7. & repurchase behavior & 75107,000 & 130053,000 & &, 219 \\
\hline 8. & retained in consumer's consideration set & 72928,000 & 127874,000 & $-1,229$ &, 072 \\
\hline 9. & result of brand expectation-performance & 70969,500 & 126247,500 & $-1,798$ &, 496 \\
\hline 10. & repurchase intention & & & &, 727 \\
\hline 11. & health advantages & 74837,000 & 181790,000 &,- 681 &, 448 \\
\hline 12. & taste & 75631,500 & 130909,500 &,- 349 &, 001 \\
\hline 13. & user convenience & 74440,000 & 129718,000 &,- 759 &, 365 \\
\hline 14. & competitive price & 65763,500 & 120709,500 & $-3,406$ &, 225 \\
\hline 15. & design of the product & 73851,000 & 129129,000 &,- 906 &, 155 \\
\hline 16. & credence quality & 72112,000 & 126397,000 & $-1,213$ &, 124 \\
\hline 17. & search quality & 72113,000 & 127391,000 & $-1,421$ &, 108 \\
\hline 18. & experience quality & 71970,500 & 127248,500 & $-1,537$ &, 054 \\
\hline 19. & way that the food product it is produced & 70623,500 & 125901,500 & $-1,931$ &, 091 \\
\hline 20. & packaging and food processing processes & 71408,500 & 126686,500 & $-1,692$ & \\
\hline
\end{tabular}

*Mann-Witney U test 
Table 9

Comparisons Among The Independent Groups*

(Grouping Variable: Age)

\begin{tabular}{|c|c|c|c|c|}
\hline & Items & $\begin{array}{c}\text { Chi-Square } \\
\text { value } \\
\end{array}$ & df & Asymp. Sig. \\
\hline 1. & company name & 34,647 & 5 & 000 \\
\hline 2. & product category attributes & 21,088 & 5 & ,001 \\
\hline 3. & consumer's emotional involvement & 18,489 & 5 &, 002 \\
\hline 4. & influences from family and friends & 21,478 & 5 & ,001 \\
\hline 5. & consumer's inertia & 1,332 & 5 & ,932 \\
\hline 6. & reduction of perceived risk by buying a well-known brand & 12,006 & 5 & 035 \\
\hline 7. & repurchase behavior & 7,231 & 5 & ,204 \\
\hline 8. & retained in consumer's consideration set & 26,869 & 5 & ,000 \\
\hline 9. & result of brand expectation-performance comparisons & 32,901 & 5 & ,000 \\
\hline 10. & repurchase intention & 40,226 & 5 &, 000 \\
\hline 11. & health advantages & 71,554 & 5 & 000 \\
\hline 12. & taste & 4,782 & 5 & ,443 \\
\hline 13. & user convenience & 23,179 & 5 & 000 \\
\hline 14. & competitive price & 50,838 & 5 & 000 \\
\hline 15. & design of the product & 40,237 & 5 & ,000 \\
\hline 16. & credence quality & 15,024 & 5 & 010 \\
\hline 17. & search quality & 31,960 & 5 &, 000 \\
\hline 18. & experience quality & 47,908 & 5 &, 000 \\
\hline 19. & way that the food product it is produced & 39,963 & 5 & 000 \\
\hline 20. & packaging and food processing processes & 36,806 & 5 &, 000 \\
\hline
\end{tabular}

*Kruskal Wallis test

Table 10

Comparisons Among The Independent Groups*

(Grouping Variable: Educational Background)

\begin{tabular}{|l|l|c|c|c|}
\hline \multicolumn{1}{|c|}{ Items } & $\begin{array}{c}\text { Chi-Square } \\
\text { value }\end{array}$ & df & Asymp. Sig. \\
\hline 1. & company name & 8,327 & 3 &, 040 \\
\hline 2. & product category attributes & 1,216 & 3 &, 749 \\
\hline 3. & consumer's emotional involvement & 9,960 & 3 &, 019 \\
\hline 4. & influences from family and friends & 15,541 & 3 &, 001 \\
\hline 5. & consumer's inertia &, 351 & 3 &, 950 \\
\hline 6. & reduction of perceived risk by buying a well-known brand & 12,117 & 3 &, 007 \\
\hline 7. & repurchase behavior & 1,995 & 3 &, 573 \\
\hline 8. & retained in consumer's consideration set & 6,429 & 3 &, 093 \\
\hline 9. & result of brand expectation-performance comparisons & 5,282 & 3 &, 152 \\
\hline 10. & repurchase intention & 23,486 & 3 &, 000 \\
\hline 11. & health advantages & 18,919 & 3 &, 000 \\
\hline 12. & taste & 20,828 & 3 &, 000 \\
\hline 13. & user convenience & 9,005 & 3 &, 029 \\
\hline 14. & competitive price & 21,195 & 3 &, 000 \\
\hline 15. & design of the product & 25,319 & 3 &, 000 \\
\hline & credence quality & 2,622 & 3 &, 454 \\
\hline & search quality & 9,158 & 3 &, 027 \\
\hline & experience quality & 12,173 & 3 &, 007 \\
\hline & way that the food product it is produced & 19,469 & 3 &, 000 \\
\hline & packaging and food processing processes &, 410 & 3 &, 938 \\
\hline
\end{tabular}

*Kruskal Wallis test 
Table 11

Comparisons Among The Independent Groups* (Grouping Variable: Place Of Adobe)

\begin{tabular}{|l|l|c|c|c|}
\hline \multicolumn{1}{|c|}{ Items } & $\begin{array}{c}\text { Chi-Square } \\
\text { value }\end{array}$ & df & Asymp. Sig. \\
\hline 1. & company name & 55,955 & 7 &, 000 \\
\hline 2. & product category attributes & 24,319 & 7 &, 001 \\
\hline 3. & consumer's emotional involvement & 128,868 & 7 &, 000 \\
\hline 4. & influences from family and friends & 24,947 & 7 &, 001 \\
\hline 5. & consumer's inertia & 20,473 & 7 &, 005 \\
\hline 6. & reduction of perceived risk by buying a well-known brand & 21,288 & 7 &, 003 \\
\hline 7. & repurchase behavior & 44,361 & 7 &, 000 \\
\hline 8. & retained in consumer's consideration set & 115,153 & 7 &, 000 \\
\hline 9. & result of brand expectation-performance comparisons & 91,514 & 7 &, 000 \\
\hline 10. & repurchase intention & 58,683 & 7 &, 000 \\
\hline 11. & health advantages & 33,865 & 7 &, 000 \\
\hline 12. & taste & 66,716 & 7 &, 000 \\
\hline 13. & user convenience & 51,786 & 7 &, 000 \\
\hline 14. & competitive price & 66,893 & 7 &, 000 \\
\hline 15. & design of the product & 73,431 & 7 &, 000 \\
\hline 16. & credence quality & 45,377 & 7 &, 000 \\
\hline 17. & search quality & 35,897 & 7 &, 000 \\
\hline 18. & experience quality & 90,801 & &, 000 \\
\hline 19. & way that the food product it is produced & 41,933 & 7 &, 000 \\
\hline 20. & packaging and food processing processes & 23,199 & 7 &, 002 \\
\hline
\end{tabular}

*Kruskal Wallis test 
NOTES 